\title{
Current treatment practice of Guillain-Barré syndrome
}

Christine Verboon, MD, Alex Y. Doets, MD, Giuliana Galassi, MD, Amy Davidson, MD, Waqar Waheed, MD, Yann Péréon, MD, PhD, Nortina Shahrizaila, FRCP, PhD, Susumu Kusunoki, MD, PhD,

Helmar C. Lehmann, MD, PhD, Thomas Harbo, MD, PhD, Soledad Monges, MD, Peter Van den Bergh, MD, PhD, Hugh J. Willison, MD, PhD, David R. Cornblath, MD, and Bart C. Jacobs, MD, PhD, on behalf of the IGOS Consortium

Neurology ${ }^{\circledR}$ 2019;93:e59-e76. doi:10.1212/WNL.0000000000007719

\section{Abstract}

\section{Objective}

To define the current treatment practice of Guillain-Barré syndrome (GBS).

\section{Methods}

The study was based on prospective observational data from the first 1,300 patients included in the International GBS Outcome Study. We described the treatment practice of GBS in general, and for (1) severe forms (unable to walk independently), (2) no recovery after initial treatment, (3) treatment-related fluctuations, (4) mild forms (able to walk independently), and (5) variant forms including Miller Fisher syndrome, taking patient characteristics and hospital type into account.

\section{Results}

We excluded 88 (7\%) patients because of missing data, protocol violation, or alternative diagnosis. Patients from Bangladesh $(\mathrm{n}=189,15 \%)$ were described separately because $83 \%$ were not treated. IV immunoglobulin (IVIg), plasma exchange (PE), or other immunotherapy was provided in 941 (92\%) of the remaining 1,023 patients, including patients with severe GBS (724/743, 97\%), mild GBS (126/168, 75\%), Miller Fisher syndrome (53/70, 76\%), and other variants $(33 / 40,83 \%)$. Of 235 (32\%) patients who did not improve after their initial treatment, $82(35 \%)$ received a second immune modulatory treatment. A treatment-related fluctuation was observed in 53 (5\%) of 1,023 patients, of whom 36 (68\%) were re-treated with IVIg or PE.

\section{Conclusions}

In current practice, patients with mild and variant forms of GBS, or with treatment-related fluctuations and treatment failures, are frequently treated, even in absence of trial data to support this choice. The variability in treatment practice can be explained in part by the lack of evidence and guidelines for effective treatment in these situations.

\author{
Correspondence \\ Dr. Jacobs \\ b.jacobs@erasmusmc.nl
}

\section{MORE ONLINE}

\section{ค Podcast}

Dr. Michelle Mauermann talks with Dr. Bart Jacobs about his paper on current treatment practice of Guillain-Barré syndrome.

NPub.org/bgclmr

\section{- CME Course}

NPub.org/cmelist

\footnotetext{
From the Departments of Neurology (C.V., A.Y.D., B.C.J.) and Immunology (B.C.J.), Erasmus MC, University Medical Center Rotterdam, the Netherlands; Department of Neurology (G.G.), University Hospital of Modena, Italy; Department of Neurology (A.D., H.J.W.), University of Glasgow, UK; Department of Neurology (W.W.), University of Vermont Medical Center, Burlington; Department of Clinical Neurophysiology (Y.P.), Reference Centre for NMD, Nantes University Hospital, France; Department of Medicine (N.S.), University of Malaya, Kuala Lumpur, Malaysia; Department of Neurology (S.K.), Kindai University Faculty of Medicine, Osaka, Japan; Department of Neurology (H.C.L.), Universitätsklinikum Köln, Germany; Department of Neurology (T.H.), Aarhus University Hospital, Denmark; Department of Neurology (S.M.), Hospital de Pediatría J.P. Garrahan, Buenos Aires, Argentina; Department of Neurology (P.V.d.B.), University Hospital St-Luc, University of Louvain, Brussels, Belgium; and Department of Neurology (D.R.C.), Johns Hopkins University School of Medicine, Baltimore, MD.

Go to Neurology.org/N for full disclosures. Funding information and disclosures deemed relevant by the authors, if any, are provided at the end of the article.
} 


\section{Glossary}

GBS = Guillain-Barré syndrome; IGOS = International GBS Outcome Study; IQR = interquartile range; IVIg = IV immunoglobulin; MFS = Miller Fisher syndrome; MP = methylprednisolone; MRC = Medical Research Council; PCB = pharyngeal-cervical-brachial weakness; PE = plasma exchange; $\mathbf{R C T}=$ randomized controlled trial; SID-GBS = Second Immunoglobulin Dose in GBS trial; TRF = treatment-related fluctuation.

Plasma exchange (PE) and IV immunoglobulin (IVIg) are the only proven effective treatments for Guillain-Barré syndrome (GBS), although there has been little formal exploration of optimal dosage and treatment duration for either. ${ }^{1,2}$ The implementation of these treatments in clinical practice is complicated by the variability in disease presentation and severity. Most therapeutic trials with PE or IVIg focused on adult patients who were unable to walk independently. ${ }^{1-3}$ At present, it is unclear whether these treatments are also effective in children, patients with mild GBS, or clinical variants including Miller Fisher syndrome (MFS). ${ }^{4,5}$ It is also unknown if treatment is still effective when administered at a later stage of the disease. Furthermore, it is not uncommon that patients continue to deteriorate or demonstrate poor recovery after initial treatment. ${ }^{6}$ In some patients, there can be subsequent deterioration after initial stabilization or recovery, a phenomenon referred to as treatment-related fluctuation (TRF). ${ }^{6}$ To date, there has been a paucity of studies describing the effects of treatment in these clinical scenarios. In the absence of adequate evidence and consensus on treatment guidelines, dilemmas continue to exist in the treatment of GBS. ${ }^{7}$ Such dilemmas may result in substantial variation in the current treatment of GBS. The aim of this study was to define the variation in current treatment practice of GBS and to identify factors that may contribute to this variation. This in turn will allow us to identify areas of variation, develop new clinical trials to address these, and initiate the development of treatment guidelines.

\section{Methods}

\section{Study design}

Data were collected from the International GBS Outcome Study (IGOS), an ongoing, prospective, observational cohort study. ${ }^{8}$ Patients were included from 154 hospitals (106 [69\%] university hospitals, including university-affiliated teaching hospitals, and 48 [31\%] non-university hospitals) in 19 countries. All patients were included within 2 weeks from onset, independent of age, disease severity, GBS variant, or treatment.

\section{Standard protocol approvals, registrations, and patient consents}

IGOS received approval from the institutional review boards from individual participating centers and written informed consent was obtained from all patients.

\section{Patient groups}

The study was based on the first 1,300 inclusions in IGOS (May 2012-January 2017). We described the type, regimen, and timing of immunotherapy. The treatment practice was related to the country of residence, clinical variant (sensorimotor, pure motor, MFS, and other variants), disease severity, and electrophysiologic subtype (demyelinating vs axonal GBS). We also compared the treatment practice in children (younger than 18 years at diagnosis) to that in adults. Patients from Bangladesh, who rarely received immunotherapy for GBS, were excluded from further analyses. ${ }^{9-11}$

In addition, we described treatment practice in the following specific clinical scenarios: (1) severe GBS, (2) severe GBS with no clinical recovery after initial treatment, (3) GBS with TRF, (4) mild GBS, and (5) GBS variants including MFS. Severe GBS was defined as being unable to walk independently at nadir (GBS disability score $\geq 3$ ) and mild GBS as being able to walk independently at nadir (GBS disability score $<3) .{ }^{12}$ Initial failure of clinical recovery was defined as worsening or failure to improve by at least one grade on the GBS disability scale from nadir to week 4 (or not improving from the first to the second week in case of a missed visit at week 4). The presence of a TRF was determined by the treating physician. Electrophysiologic subtypes were defined by the first nerve conduction study based on local reference values and the Hadden et al. ${ }^{13}$ criteria.

\section{Data collection}

We collected data on demographics (age, sex, country of residence) and clinical characteristics including disease severity (GBS disability score, limb weakness, sensory deficits, facial, bulbar, and oculomotor weakness, pain, and autonomic dysfunction) at entry and 1, 2, and 4 weeks follow-up. Documentation of autonomic dysfunction was left to the discretion of the treating physician and was defined as cardiac, blood pressure, gastro-enteric, bladder, pupil, or other autonomic dysfunction. Limb muscle strength was recorded by the Medical Research Council (MRC) sum score, ranging from 60 (full muscle strength) to 0 (total paralysis). ${ }^{14}$ The disability caused by GBS was defined by the highest GBS disability score in the first 4 weeks after study entry (nadir), ranging from 0 (healthy) to 6 (dead). ${ }^{15}$ When assessing treatment practice in patients without clinical recovery or with GBS-TRF, second-line treatment that was provided as part of a clinical trial (e.g., Second Immunoglobulin Dose in GBS trial [SID-GBS $]^{16}$ and Inhibition of Complement Activation in GBS trial [ICA-GBS $]^{17}$ ) was not taken into account. Disease severity during a TRF was defined by the GBS disability score and MRC sum score. When a TRF occurred between 2 consecutive study visits, the data recorded at the 
first visit after the TRF were used to determine severity of symptoms.

\section{Statistical analysis}

We analyzed the data using SPSS Statistics version 24 (SPSS Inc., Chicago, IL). Continuous data were presented as medians with interquartile ranges (IQR) and were compared with Mann-Whitney $U$ test. Categorical data were presented as proportions with percentages and were compared with $\chi^{2}$ or Fisher exact tests. A 2 -sided $p$ value $<0.05$ was considered significant.

\section{Data availability statement}

Data collected in IGOS will be used initially for planned research projects conducted by the IGOS Consortium. Some data will be made available from the corresponding author, upon reasonable request. The data are not publicly available because they contain information that could compromise the privacy of our patients.

\section{Results}

\section{Study cohort}

From the IGOS 1,300 cohort, we excluded 71 (5\%) patients who had an alternative diagnosis, $6(0.5 \%)$ due to protocol violation, and $11(0.8 \%)$ due to insufficient data (figure 1 ). The remaining 1,212 (93\%) patients originated from the following continents: Europe $n=664$ (55\%), Asia $n=277$ (23\%), North and South America $\mathrm{n}=238$ (20\%), Africa $\mathrm{n}=$ $25(2 \%)$, and Australia $\mathrm{n}=8(1 \%)$. Most of these patients were included by university hospitals $(n=978,81 \%)$. In the Asian group, 189 patients were from Bangladesh. The majority of Bangladeshi patients were not able to walk independently at nadir $(n=174,92 \%)$, but $144(83 \%)$ of these severely affected patients did not receive immunotherapy. Of the remaining 30 patients who did receive immunotherapy, 16 (9\%) received PE, 12 (7\%) IVIg, 1 (1\%) small volume PE, and 1 (1\%) dexamethasone monotherapy. Since the treatment practice in the Bangladesh cohort deviated strongly from that of other countries, these patients were excluded from further analyses, leaving the Asian group with 88 patients.

\section{Initial treatment}

Of the remaining study cohort of 1,023 patients, 941 (92\%) received immunomodulatory treatment. Most patients were initially treated with IVIg $(n=862,84 \%)$, which was started within a median of 4 days after the onset of symptoms (IQR $2-7)$. IVIg was initiated after 2 weeks in 18 (2\%) patients, and after 4 weeks in 5 (1\%) patients. A total IVIg dosage of $2 \mathrm{~g} / \mathrm{kg}$ body weight was given in 5 days in 754 (87\%) patients, in 2 days in 61 (7\%) patients, in 3-4 days in 36 (4\%) patients, and in 6-7 days in 8 (1\%) patients. Two patients received $2.5 \mathrm{~g} / \mathrm{kg}$ in 5 days. In 36 (4\%) of the 1,001 administered IVIg courses, methylprednisolone (MP) was used as add-on treatment. Sixty-seven patients (7\%) were initially treated with PE within a median of 6 days (IQR 3-9) after onset of symptoms. Most patients underwent $5 \mathrm{PE}$ sessions ( $\mathrm{n}=47,70 \%)$. Others received 2 sessions $(n=2,3 \%), 3$ sessions $(n=2,3 \%), 4$ sessions $(n=9,13 \%), 6$ sessions $(n=6,9 \%)$, or 7 sessions $(\mathrm{n}=1,1 \%)$. The PE sessions were performed during a median of 8 days (IQR 6-9, range 2-16).

Eight (1\%) patients were initially treated with other treatments, such as monotherapy with corticosteroids $(n=5)$ or immunoadsorption $(n=3)$. Of the 5 patients initially treated with corticosteroids only, one received an additional course of IVIg, and one received 2 additional courses of IVIg with MP add-on.

The remaining $86(8 \%)$ patients in the study cohort received no immunotherapy. Fifty-seven $(66 \%)$ of these patients had mild GBS, and 22 (26\%) had MFS or another local variant (sensory ataxic GBS, $\mathrm{n}=6$; pharyngeal-cervical-brachial variant, $\mathrm{n}=1$ ).

\section{Treatment of severe GBS}

There were 743 (81\%) patients with severe GBS who were unable to walk independently at nadir (figure 1). In the majority of countries, these patients were treated with IVIg (57\%-100\%) (figure 2). PE was seldom administered (about $4 \%$ ) except in Malaysia (33\%), Italy (30\%), and the United States (15\%). Immunoadsorption was applied only in Germany, where it was administered in $3(8 \%)$ of the 36 severely affected patients. There were no differences in the type of initial treatment (IVIg, PE, or other) in severely affected patients with sensorimotor GBS vs the pure motor variant, or between demyelinating and axonal subtypes of GBS. However, patients with the axonal subtype $(n=16 / 42,38 \%)$ were more often treated with multiple courses than patients with the demyelinating subtype $(n=49 / 296,17 \% ; p=0.001)$. Axonal GBS was associated with more severe limb weakness (indicated by lower MRC sum score) during the first 4 weeks as compared to demyelinating GBS.

\section{Treatment of patients not improving after initial treatment}

In 235 (32\%) of the 743 severely affected patients, we observed no initial clinical improvement on the GBS disability scale from nadir to 4 weeks (excluding patients with a TRF). A second immunotherapy was instituted in 82 (35\%) of these patients, most often in the Americas $(n=26 / 55,47 \%)$, compared to Europe $(\mathrm{n}=50 / 159,31 \%, p=0.04)$ and Asia $(\mathrm{n}=6 / 15,40 \%, p=0.77)$ (table). The proportion of patients who received a second immunotherapy did not differ between university $(\mathrm{n}=59 / 179,33 \%)$ and non-university hospitals ( $n=23 / 56,41 \%, p=0.27)$. Of the $211 \mathrm{IVIg}$-treated patients without initial clinical improvement, 73 (35\%) received additional immunotherapy. Most patients received a second course of IVIg $(\mathrm{n}=48,66 \%)$, which was started at median 12 days (IQR 8-17) after completing the first IVIg course. In other IVIg-treated patients, the treating physician switched to PE $(n=22,30 \%)$, which was started within 2 weeks after completing IVIg in $17(77 \%)$ of the 22 patients (median 6 


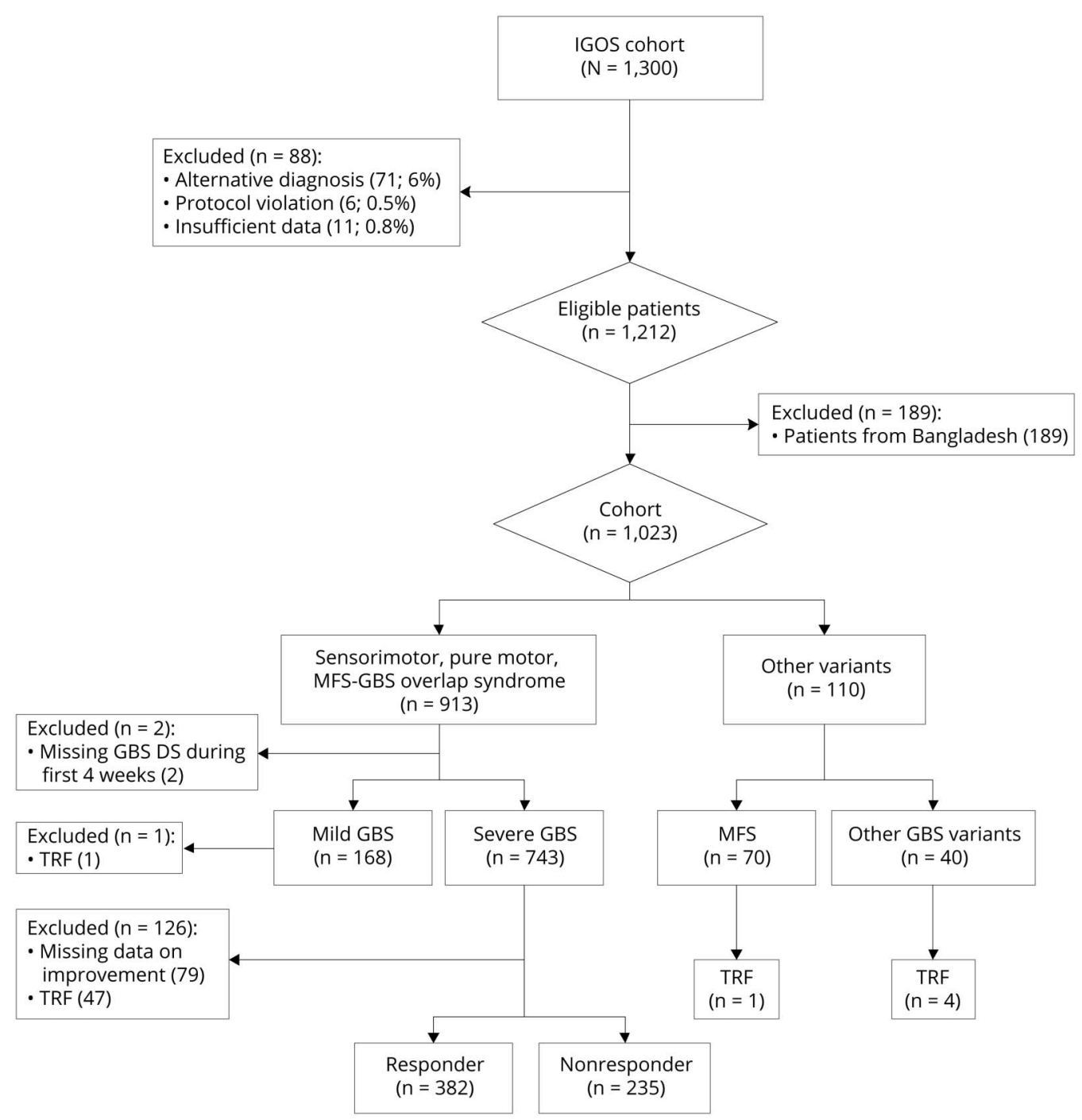

Nonresponder was defined as worsening or failure to improve by at least one grade on the Guillain-Barré syndrome (GBS) disability scale from nadir to week 4 (or not improving from the first to the second week in case of a missed visit at week 4). ${ }^{27}$ Other GBS variants = pharyngeal-cervical-brachial, sensory ataxic Bickerstaff brainstem encephalitis, and bilateral facial weakness. GBS DS = GBS disability score; IGOS = International GBS Outcome Study; MFS = Miller Fisher syndrome; TRF = treatment related fluctuation.

days, IQR 3-13). Three other IVIg-treated patients received other forms of immunotherapy. Twenty-three (11\%) of 211 IVIg-treated patients received a third, fourth, or fifth immunotherapy (figure 3).

Of the 17 PE-treated patients not showing clinical recovery in the first 4 weeks, 8 (47\%) received additional immunotherapy. In 7 (41\%) of these, the treating physician switched to IVIg after a median time of 2 days (IQR $1-4)$ after completing PE. One (6\%) patient was re-treated with a second round of PE sessions. Three (18\%) of 17 PE-treated patients received a third immunotherapy (figure 3 ).

\section{Treatment of TRFs}

A TRF occurred in 53 (5\%) of 1,023 patients included in this study (figure 1). TRFs occurred at a median of 23 days (IQR
16-31) after the start of initial treatment. Of the 50 patients initially treated with IVIg, 31 (62\%) were re-treated with IVIg for their TRF. In 4 (8\%) other patients, the physician switched treatment from IVIg to PE. Of the 3 patients initially treated with PE, one was retreated with IVIg. The remaining 17 (32\%) patients received no treatment for their TRF. In patients who were re-treated for their TRF, the TRF occurred at an earlier time point than in untreated patients (median time to TRF after start of initial treatment [IQR]: treated 21 days [14-27], untreated 32 days [25-54], $p=0.008)$. In addition, a higher proportion of treated patients was unable to walk independently around the time of the TRF (treated $\mathrm{n}=$ $33 / 36$ [92\%], untreated $n=10 / 17$ [59\%]; $p=0.008)$, and the MRC sum score was lower (median MRC sum score [IQR]: treated $41[18-51]$, untreated $49[43-60] ; p=0.019)$. Finally, patients admitted to a university hospital were more often re- 
Figure 2 Country-specific initial treatment of severely affected patients with Guillain-Barré syndrome (GBS)

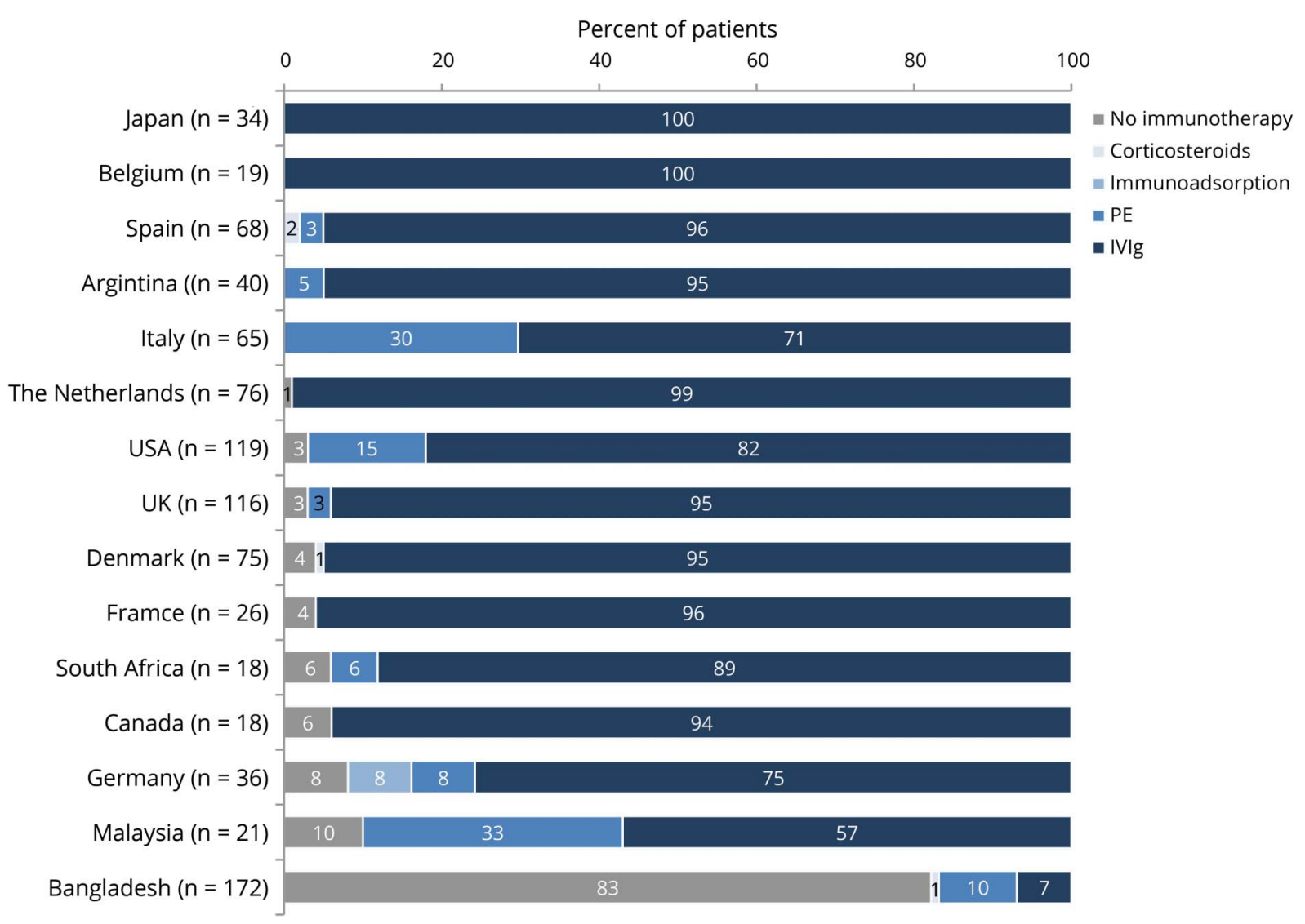

This figure contains data from countries that have included at least 10 patients in the International GBS Outcome Study (IGOS). IVIg = IV immunoglobulin; PE = plasma exchange.

treated for their TRF $(\mathrm{n}=31 / 39,80 \%)$ than those admitted to a non-university hospital $(\mathrm{n}=5 / 14,36 \%, p=0.01)$.

\section{Treatment of mild GBS}

Of the cohort of 913 patients with limb weakness, 168 (18\%) had a mild form of GBS and were still able to walk independently at nadir. In this group of patients, 126 (75\%) were treated with immunotherapy, being either IVIg in 121 $(72 \%)$ or PE in $5(3 \%)$ patients. The remaining $42(25 \%)$ received no immunotherapy. The proportion of mildly affected patients receiving immunotherapy varied among countries, and was highest in the Americas (82\%), followed by Asia (75\%) and Europe (74\%, table) (Americas vs Europe $p=$ 0.32 , Americas vs Asia $p=0.68$ ). The subgroup of patients with mild GBS receiving immunotherapy more often had autonomic dysfunction in the first 4 weeks from study entry ( $\mathrm{n}=29 / 126,23 \%)$ compared to those with mild GBS not receiving immunotherapy $(\mathrm{n}=2 / 42,5 \%, p=0.01)$. The most frequently reported autonomic symptoms were blood pressure fluctuations $(\mathrm{n}=14 / 126,11 \%)$, gastro-enteric dysfunction $(n=10 / 126,8 \%)$, bladder dysfunction $(n=9 / 126,7 \%)$, and cardiac dysfunction $(n=8 / 126,6 \%)$. The treated vs the untreated patients with mild GBS did not differ with respect to age, sex, MRC sum score, GBS disability score, cranial nerve dysfunction, sensory deficits, ataxia, or pain during the first 4 weeks after study entry. There was no difference in treatment provided by university $(\mathrm{n}=97 / 132,74 \%)$ vs nonuniversity hospitals $(\mathrm{n}=29 / 36,81 \%, p=0.39)$.

\section{Treatment of MFS and other variants}

In the study cohort, 70 (7\%) patients had MFS, and 40 (4\%) patients had another distinct variant form of GBS. The patients with MFS were treated with IVIg $(\mathrm{n}=49,70 \%), \mathrm{PE}(\mathrm{n}=2$, $3 \%)$, or other immunotherapy $(\mathrm{n}=2,3 \%)$, and $17(24 \%)$ received no treatment. In Europe $(\mathrm{n}=33 / 38,87 \%)$ and America ( $\mathrm{n}=13 / 18,72 \%)$, more patients with MFS received immunotherapy than in Asia, where 6 out of $11(55 \%)$ of the MFS patients were treated (Europe vs Asia $p=0.03$, America vs Asia $p=0.43)$. The subgroup of treated MFS patients slightly more often reported pain during the first 4 weeks ( $\mathrm{n}=$ $26 / 53,49 \%)$ than the untreated patients ( $n=4 / 17,24 \%, p=$ 0.064). The decision to treat a patient with MFS was not associated with the clinical phenotype or type of hospital. The rare variants of GBS included sensory ataxic GBS $(n=24)$, pharyngeal cervical brachial variant $(\mathrm{n}=13)$, Bickerstaff brainstem encephalitis $(n=2)$, and bilateral facial weakness $(\mathrm{n}=1)$. Thirty patients $(75 \% ; 15$ sensory ataxic, 12 pharyngeal-cervical-brachial weakness $[P C B], 2$ Bickerstaff 
Table Regional differences in treatment of subgroups of patients with Guillain-Barré syndrome (GBS)

\begin{tabular}{|c|c|c|c|c|}
\hline Clinical situation and treatment & Full cohort $(n=1,023)$ & Europe $(n=664)$ & America $(n=238)$ & $\operatorname{Asia}^{a}(n=88)$ \\
\hline Severe GBS & $n=743$ & $\mathrm{n}=485$ & $\mathrm{n}=177$ & $\mathrm{n}=57$ \\
\hline IVlg & $662(89)$ & $442(91)$ & $152(86)$ & $46(81)$ \\
\hline PE & $56(8)$ & $27(6)$ & $20(11)$ & $9(16)$ \\
\hline Other & $6(1)$ & $5(1)$ & $0(0)$ & $0(0)$ \\
\hline None & $19(3)$ & $11(2)$ & $5(3)$ & $2(4)$ \\
\hline Nonimproving & $\mathrm{n}=235$ & $n=159$ & $n=55$ & $n=15$ \\
\hline Second immunotherapy ${ }^{b}$ & $82(35)$ & $50(31)$ & $26(47)$ & $6(40)$ \\
\hline TRF & $n=53$ & $n=45$ & $n=7$ & $\mathrm{n}=0$ \\
\hline Second immunotherapy ${ }^{2, b}$ & $36(68)$ & $31(69)$ & $5(71)$ & na \\
\hline Mild GBS & $n=168$ & $n=112$ & $\mathrm{n}=39$ & $\mathrm{n}=12$ \\
\hline IVIg & $121(72)$ & $80(71)$ & $31(79)$ & $8(67)$ \\
\hline PE & $5(3)$ & $3(3)$ & 1 (3) & $1(8)$ \\
\hline None & $42(25)$ & $29(26)$ & 7 (18) & $3(25)$ \\
\hline MFS & $\mathrm{n}=70$ & $n=38$ & $\mathrm{n}=18$ & $\mathrm{n}=11$ \\
\hline IVIg & $49(70)$ & $30(79)$ & $12(67)$ & $6(55)$ \\
\hline PE & $2(3)$ & $1(3)$ & $1(6)$ & $0(0)$ \\
\hline Other & $2(3)$ & $2(5)$ & $0(0)$ & $0(0)$ \\
\hline None & $17(24)$ & $5(13)$ & $5(28)$ & $5(46)$ \\
\hline
\end{tabular}

Abbreviations: IVIg = IV immunoglobulin; MFS = Miller Fisher syndrome; PE = plasma exchange; TRF = treatment-related fluctuation.

Values are $\mathrm{n}(\%)$.

a Asia not including Bangladesh.

${ }^{\mathrm{b}}$ Consisting of IVIg, PE, or corticosteroids alone.

brainstem encephalitis, and 1 bilateral facial weakness) were treated with IVIg, 3 ( $8 \%$; all sensory ataxic) with $\mathrm{PE}$, and 7 (18\%; 6 sensory ataxic, $1 \mathrm{PCB})$ received no therapy.

\section{Treatment of children}

There were $60(6 \%)$ children aged below 18 years (median 4 years, IQR 2-12), of whom 53 (90\%) were unable to walk independently at nadir. Five (8\%) were not treated with immunotherapy; they all had mild GBS. All others received IVIg. Children were similarly treated in university and non-university hospitals. Compared to adults, children were more often treated with a 2-day IVIg regimen (children $n=30 / 54,56 \%$ vs adults $\mathrm{n}=31 / 775,4 \%$ ) than a 5-day regimen (children $\mathrm{n}=24$ / $54,44 \%$ vs adults $n=744 / 775,96 \%, p<0.001$ ). A considerable subgroup of children $(\mathrm{n}=23)$ came from Argentina, who were all treated with IVIg $2 \mathrm{~g} / \mathrm{kg}$ in 2 days.

\section{Discussion}

This study demonstrates a considerable variation in the current treatment practice of patients with GBS. Our study showed that in high-income countries, nearly all patients with severe GBS received initial treatment with IVIg or PE. In patients without clinical improvement, about one-third received a second treatment. Patients developing a secondary deterioration after initial stabilization or improvement (TRF) were retreated in only two-thirds of cases. Patients with a milder form of GBS who were still able to walk independently were treated with IVIg or PE in $75 \%$ of cases. A similar proportion of patients with MFS or other (local) variants received this immunotherapy. The observed variation in treatment of GBS is in part explained by the lack of therapeutic trials that have investigated treatment efficacy in these specific clinical situations.

IVIg was the first choice of treatment in $92 \%$ of treated GBS patients. Most patients received the recommended dosage of $2 \mathrm{~g} / \mathrm{kg}$ body weight in 5 days, but some received a 2 -day regimen. Children were more frequently treated with the latter scheme, presumably because this is better tolerated in young children. The optimal regimen of IVIg for GBS is currently undefined, but a randomized controlled trial (RCT) comparing a 5-and 2-day regimen in children indicated that a 2-day regimen is equally effective, but is more frequently followed by a TRF. ${ }^{18}$ Methylprednisolone was provided as 


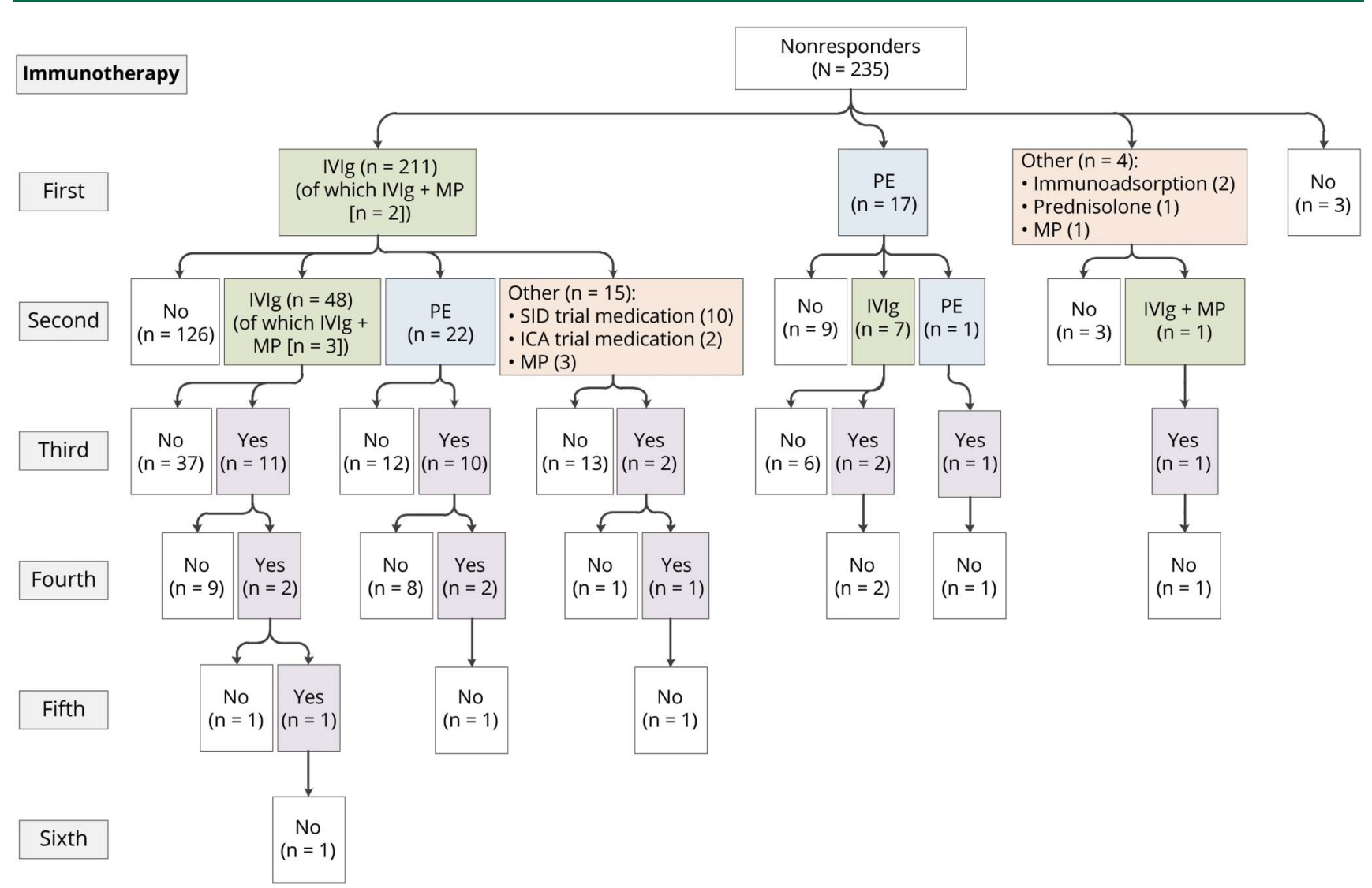

Treatment of 235 patients with a severe form of GBS who showed no improvement after initial treatment. ICA-GBS = Inhibition of Complement Activation in GBS trial; IVIg = IV immunoglobulins; MP = methylprednisolone; PE = plasma exchange; SID-GBS = Second Immunoglobulin Dose in GBS trial.

add-on treatment in only $4 \%$ of the total number of administered IVIg courses. A single RCT indicated a short-term effect of MP as add-on to IVIg after correction for known prognostic factors, but showed no difference in improvement on the GBS disability scale. ${ }^{7,19}$ PE was provided as initial treatment in $7 \%$ of treated patients, and the proportion of PEtreated patients depended on the country of origin. PE is considered equally effective to IVIg for GBS, and the local preference may depend upon presence of contraindications to IVIg, the availability of resources, health care insurance, or protocols. $^{1-3,20,21}$ The number of sessions and duration of treatment with $\mathrm{PE}$ varied between patients. One trial investigated the optimal number of PE sessions and found that 4 sessions were better than 2, but equally effective to 6 sessions in relation to time to walk with aid and time on a ventilator. ${ }^{12}$ Immunoadsorption was instituted only in Germany, where 2 immunoadsorption trials were conducted. This may explain why the use was limited to German centers, in addition to reimbursement differences and costs. ${ }^{22,23}$ Some patients were treated with corticosteroids only, even though this treatment is considered ineffective for GBS. ${ }^{24}$ The treatment practice in high-income countries is in marked contrast with the situation in Bangladesh, where only $15 \%$ of patients with severe GBS received immunotherapy. Most inhabitants of Bangladesh cannot afford treatment with either IVIg or PE. ${ }^{9,10}$ Low-cost alternative treatments for GBS are required and small volume plasma exchange is currently under investigation. ${ }^{25}$

Multiple treatment courses were administered in patients without improvement after initial treatment. In severely affected patients who did not improve after a first treatment with IVIg or PE, 35\% received a second treatment, $11 \%$ a third treatment, and some even a fourth and a fifth treatment. Patients who received multiple courses of treatment more often had axonal GBS, which in the IGOS cohort is associated with more severe limb weakness, and could have influenced the decision to repeat treatment. ${ }^{11}$ The efficacy of a second course of IVIg is yet unknown, but is currently investigated in SID-GBS trial. ${ }^{16}$ In some of these patients initially treated with IVIg, the treating physician switched to PE, which was often started within 2 weeks of completion of IVIg. While the efficacy of this treatment practice is unproven, one may argue that IVIg and PE have different therapeutic targets and that if one treatment fails, the other might still be effective. A consequence of this early secondary treatment with $\mathrm{PE}$ is that IVIg is washed out and cannot further contribute to the recovery. ${ }^{7}$ Other patients were treated with PE followed by IVIg. Previously, an RCT comparing PE or IVIg alone to PE 
followed by IVIg showed no difference in outcome. ${ }^{20}$ This trial was not designed to address IVIg treatment efficacy in patients not responding to PE.

Another group of patients receiving secondary treatments were those with a TRF. Previous studies have shown that TRFs may occur in up to $12 \%$ of GBS patients. ${ }^{11}$ In the current study, TRFs were reported in $53(5 \%)$ patients, of whom $68 \%$ were re-treated with IVIg or PE. A higher proportion of re-treated TRF patients was unable to walk independently and the treated group had more severe limb weakness around the time of the TRF, which indicates that the decision to start treatment in case of a TRF may depend on the severity of symptoms. In addition, re-treatment for a TRF was more often provided in university vs non-university hospitals. No trials have investigated the efficacy of treatment of a TRF in patients with GBS. The rationale for re-treatment of TRFs is that these likely result from a transient effect of the first treatment in a patient with ongoing disease activity. ${ }^{3,7}$ Yet $32 \%$ of patients with a TRF in the study cohort received no additional treatment.

Although the treatment efficacy of IVIg and PE was largely demonstrated in patients with GBS unable to walk, our study showed that in current clinical practice, $75 \%$ of patients with mild disability were also treated. One RCT demonstrated that in patients with mild GBS, 2 sessions of PE shortened the time to onset of motor recovery and hospital discharge compared to supportive care only. ${ }^{12}$ Moreover, more than three-quarters of patients with MFS and other variants of GBS were treated with IVIg or PE, despite the fact that treatment efficacy has not been demonstrated for these subgroups and the prognosis of MFS in general is considered to be good independent of treatment. ${ }^{26}$ In our study cohort, patients with MFS had a higher chance of receiving immunotherapy in Europe and America compared to Asia. The decision to start treatment may have been prompted by the higher frequency of autonomic dysfunction in patients with mild GBS, and pain in patients with MFS. No other differences were found between the treated and untreated patients with mild GBS and MFS.

The decision to treat may have been influenced by the expertise of the treating clinician and the policy in the local hospitals. University hospitals were overrepresented in the IGOS Consortium, although the treatment practice did not differ from non-university hospitals except in the situation of a TRF. In addition, clinicians with a special interest in GBS are likely overrepresented. This may have resulted in an underestimation of the variation in treatment practice because of their expertise, or in an overestimation because of the access to multiple treatment options in tertiary reference centers. We were not able to assess the effect of expertise and years of clinical experience on treatment practice, because this information was not collected in IGOS. Another limitation of the study was that while the IGOS aims to include the full spectrum of GBS and variants, the included patient population may be biased, especially towards more severe cases. In addition, data were collected in IGOS at standard time points, and changes between visits that may have prompted the decision to start treatment are possibly unobserved. This limitation could also have influenced the number of TRFs, which is relatively low compared to other studies. Furthermore, data on the GBS treatment practice in regions and countries not represented in IGOS are lacking.

The treatment practice currently provided for GBS varies between patients, especially with respect to initial treatment of mild and variant forms, and retreatment of TRF and nonresponding patients. Such treatment could be beneficial in terms of clinical outcome and cost-effectiveness, but selective treatment trials are lacking and complicated because of the rarity and diversity of GBS. Whether such evidence can be generated by comparative treatment studies based on observational data needs to be determined. Further studies are required to develop evidence-based guidelines on the treatment of GBS.

\section{Acknowledgment}

The authors thank the patients who participated in this longterm follow-up study.

\section{Study funding}

This study is funded by the GBS-CIDP Foundation International, Gain, Erasmus MC University Medical Centre Rotterdam, Glasgow University, CSL Behring, Grifols, and Annexon.

\section{Disclosure}

C. Verboon, A. Doets, G. Galassi, A. Davidson, and W. Waheed report no disclosures relevant to the manuscript. Y. Péréon has received research support from CSL Behring and speaker honoraria from LFB, Natus, Pfizer, Novartis, and Boehringer. N. Shahrizaila reports no disclosures relevant to the manuscript. S. Kusunoki reports speech honoraria from Teijin, Japan Blood Product Organization, and Nihon Pharmaceutical, and grants from the Ministry of Health, Labor and Welfare of Japan, The Japan Agency for Medical Research and Development, and Ministry of Education, Culture, Sports, Science and Technology of Japan. H. Lehmann has received personal compensation from Akcea, Alnylam, Celgene, CSL Behring, Grifols, Novartis, and Takeda for consulting services and speaking at scientific symposia. T. Harbo Has received speaker's honoraria from CSL Behring. S. Monges reports no disclosures relevant to the manuscript. P. Van den Bergh has received honoraria and consultation fees from, or served on the advisory board for, Pfizer, Genzyme, CSL Behring, LFB, Natus, UCB Pharma, and Alnylam; has participated in a company-sponsored speaker's bureau for Pfizer, LFB, Natus, and CSL Behring; and has received travel assistance, reimbursement of conference registration, and hotel charges for several Peripheral Nerve Society meetings from LFB, Genzyme, and CSL Behring. $\mathrm{H}$. Willison serves on the editorial boards of several neurology and neuroimmunology journals, receives research funding the Medical Research Council, Wellcome Trust, and European Union, serves on the Scientific Advisory Board for Annexon Biosciences, has provided 
scientific or medical advice to Johnson \& Johnson, Janssen Vaccines AG, Syntimmune, Hansa Medical, and Minnetronix, and received funding to support meeting costs from Baxalta, CSL Behring, Grifols, Kendrion SpA, LFB Biomedicaments, Octapharma, TEVA, Buhlmann Laboratories, and Syntimmune. D. Cornblath is a consultant for Acetylon, Alcobra Pharma, Alnylam Pharmaceuticals, Annexon Biosciences, Akros Pharma, Biotest Pharmaceuticals, Boehringer Ingelheim, Cigna Health Management, CSL Behring, DP Clinical, Grifols, Hansa Medical, Karos Pharmaceuticals, Neurocrine Biosciences, Novartis, Octapharma, Pharnext, Seattle Genetics, Sun Pharmaceuticals, and Syntimmune; is on the data and safety monitoring board for Sanofi, Pledpharma, Pfizer, Johnson \& Johnson, Ionis Pharmaceuticals, GlaxoSmithKline, and Axovant Sciences; has licensed technology for the Total Neuropathy Score for Acetylon, AstraZeneca, Calithera Biosciences, Genentech, Neurocrine Biosciences, Merrimack Pharmaceuticals, Seattle Genetics, and Shire Development Inc.; and is on the Board of Directors for the Peripheral Nerve Society. B. Jacobs has received funding for research projects from Prinses Beatrix Spierfonds, Horizon 2020, GBS-CIDP Foundation International, Grifols, CSL Behring, and Annexon; is on the Medical Advisory Board for the GBS-CIDP Foundation International; and is a member of the Inflammatory Neuropathy Consortium. Go to Neurology.org/N for full disclosures.

\section{Publication history}

Received by Neurology October 30, 2018. Accepted in final form February 13, 2019.

Appendix 1 Authors

\begin{tabular}{|c|c|c|c|}
\hline Name & Location & Role & Contribution \\
\hline $\begin{array}{l}\text { Christine } \\
\text { Verboon, } \\
\text { MD }\end{array}$ & $\begin{array}{l}\text { Erasmus MC, } \\
\text { University Medical } \\
\text { Center Rotterdam, } \\
\text { the Netherlands }\end{array}$ & Author & $\begin{array}{l}\text { Designed and } \\
\text { conceptualized study, } \\
\text { analyzed the data, } \\
\text { drafted the } \\
\text { manuscript for } \\
\text { intellectual content, } \\
\text { member of the IGOS } \\
\text { Coordinating Centre, } \\
\text { IGOS Country } \\
\text { Coordinator, patient } \\
\text { inclusion, acquisition } \\
\text { of data }\end{array}$ \\
\hline
\end{tabular}

\begin{tabular}{|c|c|c|c|}
\hline $\begin{array}{l}\text { Alex Y. } \\
\text { Doets, MD }\end{array}$ & $\begin{array}{l}\text { Erasmus MC, } \\
\text { University Medical } \\
\text { Center Rotterdam, } \\
\text { the Netherlands }\end{array}$ & Author & $\begin{array}{l}\text { Designed and } \\
\text { conceptualized study, } \\
\text { analyzed the data, } \\
\text { drafted the } \\
\text { manuscript for } \\
\text { intellectual content, } \\
\text { member of the IGOS } \\
\text { Coordinating Centre, } \\
\text { IGOS Country } \\
\text { Coordinator, patient } \\
\text { inclusion, acquisition } \\
\text { of data }\end{array}$ \\
\hline
\end{tabular}

\begin{tabular}{lll}
\hline Giuliana & University Hospital of & Author \\
Galassi, MD & Modena, Italy & $\begin{array}{l}\text { Interpreted the data, } \\
\text { revised the } \\
\text { manuscript for } \\
\text { intellectual content, } \\
\text { patient inclusion, } \\
\text { acquisition of data }\end{array}$ \\
\end{tabular}

Appendix 1 (continued)

\begin{tabular}{|c|c|c|c|}
\hline Name & Location & Role & Contribution \\
\hline $\begin{array}{l}\text { Amy } \\
\text { Davidson, } \\
\text { MD }\end{array}$ & $\begin{array}{l}\text { University of } \\
\text { Glasgow, UK }\end{array}$ & Author & $\begin{array}{l}\text { Interpreted the data, } \\
\text { revised the manuscript } \\
\text { for intellectual content, } \\
\text { IGOS Country } \\
\text { Coordinator, patient } \\
\text { inclusion, acquisition of } \\
\text { data }\end{array}$ \\
\hline $\begin{array}{l}\text { Waqar } \\
\text { Waheed, } \\
\text { MD }\end{array}$ & $\begin{array}{l}\text { University of } \\
\text { Vermont Medical } \\
\text { Center, Burlington }\end{array}$ & Author & $\begin{array}{l}\text { Interpreted the data, } \\
\text { revised the } \\
\text { manuscript for } \\
\text { intellectual content, } \\
\text { patient inclusion, } \\
\text { acquisition of data }\end{array}$ \\
\hline $\begin{array}{l}\text { Yann } \\
\text { Péréon, MD, } \\
\text { PhD }\end{array}$ & $\begin{array}{l}\text { Reference Centre for } \\
\text { NMD, Nantes } \\
\text { University Hospital, } \\
\text { France }\end{array}$ & Author & $\begin{array}{l}\text { Interpreted the data, } \\
\text { revised the manuscript } \\
\text { for intellectual content, } \\
\text { IGOS Country } \\
\text { Coordinator, patient } \\
\text { inclusion, acquisition of } \\
\text { data }\end{array}$ \\
\hline
\end{tabular}

\begin{tabular}{|c|c|c|c|}
\hline $\begin{array}{l}\text { Nortina } \\
\text { Shahrizaila, } \\
\text { FRCP, PhD }\end{array}$ & $\begin{array}{l}\text { University of Malaya, } \\
\text { Kuala Lumpur, } \\
\text { Malaysia }\end{array}$ & Author & $\begin{array}{l}\text { Interpreted the data, } \\
\text { revised the manuscript } \\
\text { for intellectual content, } \\
\text { IGOS Country } \\
\text { Coordinator, patient } \\
\text { inclusion, acquisition of } \\
\text { data }\end{array}$ \\
\hline
\end{tabular}

\begin{tabular}{lll}
\hline Susumu & Kindai University $\quad$ Author & $\begin{array}{l}\text { Interpreted the data, } \\
\text { Kusunoki, }\end{array}$ \\
Faculty of Medicine, & & revised the
\end{tabular}

MD, PhD Osaka, Japan manuscript for intellectual content, member of the IGOS Steering Committee, IGOS Country Coordinator, patient inclusion, acquisition of data

\begin{tabular}{|c|c|c|c|}
\hline $\begin{array}{l}\text { Helmar C. } \\
\text { Lehmann, } \\
\text { MD, PhD }\end{array}$ & $\begin{array}{l}\text { University Hospital of } \\
\text { Cologne, } \\
\text { Universitätsklinikum } \\
\text { Köln, Germany }\end{array}$ & Author & $\begin{array}{l}\text { Interpreted the data, } \\
\text { revised the } \\
\text { manuscript for } \\
\text { intellectual content, } \\
\text { IGOS Country } \\
\text { Coordinator, patient } \\
\text { inclusion, acquisition } \\
\text { of data }\end{array}$ \\
\hline
\end{tabular}

Thomas Aarhus University Author Interpreted the data,

Harbo, MD, Hospital, Denmark revised the

PhD manuscript for intellectual content, IGOS Country Coordinator, patient inclusion, acquisition of data

\begin{tabular}{|c|c|c|c|}
\hline $\begin{array}{l}\text { Soledad } \\
\text { Monges, MD }\end{array}$ & $\begin{array}{l}\text { Hospital de Pediatría } \\
\text { J.P. Garrahan, } \\
\text { Buenos Aires, } \\
\text { Argentina }\end{array}$ & Author & $\begin{array}{l}\text { Interpreted the data, } \\
\text { revised the } \\
\text { manuscript for } \\
\text { intellectual content, } \\
\text { patient inclusion, } \\
\text { acquisition of data }\end{array}$ \\
\hline $\begin{array}{l}\text { Peter Van } \\
\text { den Bergh, } \\
\text { MD, PhD }\end{array}$ & $\begin{array}{l}\text { University Hospital } \\
\text { St-Luc, University of } \\
\text { Louvain, Brussels, } \\
\text { Belgium }\end{array}$ & Author & $\begin{array}{l}\text { Interpreted the data, } \\
\text { revised the } \\
\text { manuscript for } \\
\text { intellectual content, } \\
\text { IGOS Country } \\
\text { Coordinator, patient } \\
\text { inclusion, acquisition } \\
\text { of data }\end{array}$ \\
\hline
\end{tabular}


Appendix 1 (continued)

\begin{tabular}{|c|c|c|c|}
\hline Name & Location & Role & Contribution \\
\hline $\begin{array}{l}\text { Hugh J. } \\
\text { Willison, } \\
\text { MD, PhD }\end{array}$ & $\begin{array}{l}\text { University of } \\
\text { Glasgow, UK }\end{array}$ & Author & $\begin{array}{l}\text { Interpreted the data, } \\
\text { revised the manuscript } \\
\text { for intellectual content, } \\
\text { member of the IGOS } \\
\text { Steering Committee, } \\
\text { IGOS Country } \\
\text { Coordinator, patient } \\
\text { inclusion, acquisition of } \\
\text { data }\end{array}$ \\
\hline
\end{tabular}

\begin{tabular}{|c|c|c|c|}
\hline $\begin{array}{l}\text { David R. } \\
\text { Cornblath, } \\
\text { MD }\end{array}$ & $\begin{array}{l}\text { Johns Hopkins } \\
\text { University School of } \\
\text { Medicine, Baltimore, } \\
\text { MD }\end{array}$ & Author & $\begin{array}{l}\text { Interpreted the data, } \\
\text { revised the } \\
\text { manuscript for } \\
\text { intellectual content, } \\
\text { member of the IGOS } \\
\text { Steering Committee, } \\
\text { patient inclusion, } \\
\text { acquisition of data }\end{array}$ \\
\hline $\begin{array}{l}\text { Bart C. } \\
\text { Jacobs, MD, } \\
\text { PhD }\end{array}$ & $\begin{array}{l}\text { Erasmus MC, } \\
\text { University Medical } \\
\text { Center Rotterdam, } \\
\text { the Netherlands }\end{array}$ & Author & $\begin{array}{l}\text { Designed and } \\
\text { conceptualized study, } \\
\text { drafted the manuscript } \\
\text { for intellectual content, } \\
\text { member of the IGOS } \\
\text { Steering Committee, } \\
\text { member of the IGOS } \\
\text { Coordinating Centre, } \\
\text { IGOS Country } \\
\text { Coordinator, patient } \\
\text { inclusion, acquisition of } \\
\text { data }\end{array}$ \\
\hline
\end{tabular}

Appendix 2 Coinvestigators

\begin{tabular}{|c|c|c|c|}
\hline Name & Location & Role & Contribution \\
\hline $\begin{array}{l}\text { R.A.C. } \\
\text { Hughes, MD }\end{array}$ & $\begin{array}{l}\text { MRC Centre } \\
\text { for Neuro- } \\
\text { muscular } \\
\text { Diseases, } \\
\text { National } \\
\text { Hospital for } \\
\text { Neurology and } \\
\text { Neurosurgery, } \\
\text { London, UK }\end{array}$ & Coinvestigator & $\begin{array}{l}\text { Member of the IGOS } \\
\text { Steering Committee }\end{array}$ \\
\hline $\begin{array}{l}\text { K.C. Gorson, } \\
\text { MD }\end{array}$ & $\begin{array}{l}\text { St. Elizabeth's } \\
\text { Medical } \\
\text { Centre, Tufts } \\
\text { University } \\
\text { School of } \\
\text { Medicine, } \\
\text { Boston, MA }\end{array}$ & Coinvestigator & $\begin{array}{l}\text { Member of the IGOS } \\
\text { Steering Committee, } \\
\text { IGOS Country } \\
\text { Coordinator, led and } \\
\text { coordinated } \\
\text { communication } \\
\text { among sites, patient } \\
\text { inclusion, acquisition } \\
\text { of data }\end{array}$ \\
\hline $\begin{array}{l}\text { H.P. } \\
\text { Hartung, } \\
\text { MD, PhD }\end{array}$ & $\begin{array}{l}\text { University of } \\
\text { Düsseldorf, } \\
\text { Germany }\end{array}$ & Coinvestigator & $\begin{array}{l}\text { Member of the IGOS } \\
\text { Steering Committee, } \\
\text { IGOS Country } \\
\text { Coordinator, led and } \\
\text { coordinated } \\
\text { communication } \\
\text { among sites, patient } \\
\text { inclusion, acquisition } \\
\text { of data }\end{array}$ \\
\hline $\begin{array}{l}\text { P.A. Van } \\
\text { Doorn, MD, } \\
\text { PhD }\end{array}$ & $\begin{array}{l}\text { Erasmus MC, } \\
\text { University } \\
\text { Medical } \\
\text { Center } \\
\text { Rotterdam, } \\
\text { the } \\
\text { Netherlands }\end{array}$ & Coinvestigator & $\begin{array}{l}\text { Member of the IGOS } \\
\text { Steering Committee, } \\
\text { patient inclusion, } \\
\text { acquisition of data }\end{array}$ \\
\hline
\end{tabular}

Appendix 2 (continued)

\begin{tabular}{|c|c|c|c|}
\hline Name & Location & Role & Contribution \\
\hline $\begin{array}{l}\text { B. Van den } \\
\text { Berg, MD }\end{array}$ & $\begin{array}{l}\text { Erasmus MC, } \\
\text { University } \\
\text { Medical } \\
\text { Center } \\
\text { Rotterdam, } \\
\text { the } \\
\text { Netherlands }\end{array}$ & Coinvestigator & $\begin{array}{l}\text { Member of the IGOS } \\
\text { Coordinating } \\
\text { Centre, foundation } \\
\text { and maintenance of } \\
\text { the study, } \\
\text { coordination of } \\
\text { communication } \\
\text { among countries } \\
\text { and sites, data } \\
\text { processing and } \\
\text { management, IGOS } \\
\text { Country } \\
\text { Coordinator, led and } \\
\text { coordinated } \\
\text { communication } \\
\text { among sites, patient } \\
\text { inclusion, } \\
\text { acquisition of data }\end{array}$ \\
\hline $\begin{array}{l}\text { J. Roodbol, } \\
\text { MD }\end{array}$ & $\begin{array}{l}\text { Erasmus MC, } \\
\text { University } \\
\text { Medical } \\
\text { Center } \\
\text { Rotterdam, } \\
\text { the } \\
\text { Netherlands }\end{array}$ & Coinvestigator & $\begin{array}{l}\text { Member of the IGOS } \\
\text { Coordinating Centre, } \\
\text { foundation and } \\
\text { maintenance of the } \\
\text { study, coordination } \\
\text { of communication } \\
\text { among countries and } \\
\text { sites, data } \\
\text { processing and } \\
\text { management, } \\
\text { patient inclusion, } \\
\text { acquisition of data }\end{array}$ \\
\hline $\begin{array}{l}\text { M. Van } \\
\text { Woerkom, } \\
\text { Research } \\
\text { Coordinator } \\
\text { IGOS }\end{array}$ & $\begin{array}{l}\text { Erasmus MC, } \\
\text { University } \\
\text { Medical } \\
\text { Center } \\
\text { Rotterdam, } \\
\text { the } \\
\text { Netherlands }\end{array}$ & Coinvestigator & $\begin{array}{l}\text { Member of the IGOS } \\
\text { Coordinating Centre, } \\
\text { foundation and } \\
\text { maintenance of the } \\
\text { study, coordination } \\
\text { of communication } \\
\text { among countries and } \\
\text { sites, data } \\
\text { processing and } \\
\text { management, } \\
\text { patient inclusion, } \\
\text { acquisition of data }\end{array}$ \\
\hline $\begin{array}{l}\text { R.C. Reisin, } \\
\text { MD }\end{array}$ & $\begin{array}{l}\text { Hospital } \\
\text { Britanico, } \\
\text { Buenos Aires, } \\
\text { Argentina }\end{array}$ & Coinvestigator & $\begin{array}{l}\text { IGOS Country } \\
\text { Coordinator, led and } \\
\text { coordinated } \\
\text { communication } \\
\text { among sites, patient } \\
\text { inclusion, acquisition } \\
\text { of data }\end{array}$ \\
\hline $\begin{array}{l}\text { S.W. Reddel, } \\
\text { MD, PhD }\end{array}$ & $\begin{array}{l}\text { Concord } \\
\text { Repatriation } \\
\text { General } \\
\text { Hospital, } \\
\text { Sydney, } \\
\text { Australia }\end{array}$ & Coinvestigator & $\begin{array}{l}\text { IGOS Country } \\
\text { Coordinator, led and } \\
\text { coordinated } \\
\text { communication } \\
\text { among sites, patient } \\
\text { inclusion, acquisition } \\
\text { of data }\end{array}$ \\
\hline Z. Islam, PhD & $\begin{array}{l}\text { International } \\
\text { Centre for } \\
\text { Diarrhoeal } \\
\text { Disease } \\
\text { Research, } \\
\text { Bangladesh, } \\
\text { Dhaka }\end{array}$ & Coinvestigator & $\begin{array}{l}\text { IGOS Country } \\
\text { Coordinator, led and } \\
\text { coordinated } \\
\text { communication } \\
\text { among sites, patient } \\
\text { inclusion, acquisition } \\
\text { of data }\end{array}$ \\
\hline B. Islam, MD & $\begin{array}{l}\text { International } \\
\text { Centre for } \\
\text { Diarrhoeal } \\
\text { Disease } \\
\text { Research, } \\
\text { Bangladesh, } \\
\text { Dhaka }\end{array}$ & Coinvestigator & $\begin{array}{l}\text { IGOS Country } \\
\text { Coordinator, led and } \\
\text { coordinated } \\
\text { communication } \\
\text { among sites, patient } \\
\text { inclusion, acquisition } \\
\text { of data }\end{array}$ \\
\hline
\end{tabular}


Appendix 2 (continued)

\begin{tabular}{|c|c|c|c|}
\hline Name & Location & Role & Contribution \\
\hline $\begin{array}{l}\text { Q.D. } \\
\text { Mohammad, } \\
\text { MD, PhD }\end{array}$ & $\begin{array}{l}\text { National } \\
\text { Institute of } \\
\text { Neurosciences } \\
\text { and Hospital, } \\
\text { Dhaka, } \\
\text { Bangladesh }\end{array}$ & Coinvestigator & $\begin{array}{l}\text { IGOS Country } \\
\text { Coordinator, led and } \\
\text { coordinated } \\
\text { communication } \\
\text { among sites, patient } \\
\text { inclusion, acquisition } \\
\text { of data }\end{array}$ \\
\hline $\begin{array}{l}\text { T.E. Feasby, } \\
\text { MD }\end{array}$ & $\begin{array}{l}\text { University of } \\
\text { Calgary, } \\
\text { Canada }\end{array}$ & Coinvestigator & $\begin{array}{l}\text { IGOS Country } \\
\text { Coordinator, led and } \\
\text { coordinated } \\
\text { communication } \\
\text { among sites, patient } \\
\text { inclusion, acquisition } \\
\text { of data }\end{array}$ \\
\hline $\begin{array}{l}\text { E. Dardiotis, } \\
\text { MD }\end{array}$ & $\begin{array}{l}\text { University of } \\
\text { Thessaly, } \\
\text { Hospital of } \\
\text { Larissa, } \\
\text { Greece }\end{array}$ & Coinvestigator & $\begin{array}{l}\text { IGOS Country } \\
\text { Coordinator, led } \\
\text { and coordinated } \\
\text { communication } \\
\text { among sites, } \\
\text { patient inclusion, } \\
\text { acquisition of } \\
\text { data }\end{array}$ \\
\hline $\begin{array}{l}\text { E. Nobile- } \\
\text { Orazio, MD, } \\
\text { PhD }\end{array}$ & $\begin{array}{l}\text { Milan } \\
\text { University, } \\
\text { Humanitas } \\
\text { Clinicala and } \\
\text { Research } \\
\text { Institute } \\
\text { Milan, Italy }\end{array}$ & Coinvestigator & $\begin{array}{l}\text { IGOS Country } \\
\text { Coordinator, led } \\
\text { and coordinated } \\
\text { communication } \\
\text { among sites, } \\
\text { patient inclusion, } \\
\text { acquisition of } \\
\text { data }\end{array}$ \\
\hline $\begin{array}{l}\text { K. Bateman, } \\
\text { MD }\end{array}$ & $\begin{array}{l}\text { Groote } \\
\text { Schuur } \\
\text { Hospital, } \\
\text { University of } \\
\text { Cape Town, } \\
\text { South Africa }\end{array}$ & Coinvestigator & $\begin{array}{l}\text { IGOS Country } \\
\text { Coordinator, led and } \\
\text { coordinated } \\
\text { communication } \\
\text { among sites, patient } \\
\text { inclusion, acquisition } \\
\text { of data }\end{array}$ \\
\hline $\begin{array}{l}\text { I. Illa, MD, } \\
\text { PhD }\end{array}$ & $\begin{array}{l}\text { Hospital de la } \\
\text { Santa Creu i } \\
\text { Sant Pau, } \\
\text { Universitat } \\
\text { Autònoma de } \\
\text { Barcelona, } \\
\text { Spain }\end{array}$ & Coinvestigator & $\begin{array}{l}\text { IGOS Country } \\
\text { Coordinator, led and } \\
\text { coordinated } \\
\text { communication } \\
\text { among sites, patient } \\
\text { inclusion, acquisition } \\
\text { of data }\end{array}$ \\
\hline $\begin{array}{l}\text { L. Querol, } \\
\text { MD, PhD }\end{array}$ & $\begin{array}{l}\text { Hospital de la } \\
\text { Santa Creu i } \\
\text { Sant Pau, } \\
\text { Universitat } \\
\text { Autònoma de } \\
\text { Barcelona, } \\
\text { Spain }\end{array}$ & Coinvestigator & $\begin{array}{l}\text { IGOS Country } \\
\text { Coordinator, led } \\
\text { and coordinated } \\
\text { communication } \\
\text { among sites, } \\
\text { patient inclusion, } \\
\text { acquisition of } \\
\text { data }\end{array}$ \\
\hline $\begin{array}{l}\text { S.T. Hsieh, } \\
\text { MD, PhD }\end{array}$ & $\begin{array}{l}\text { National } \\
\text { Taiwan } \\
\text { University } \\
\text { Hospital, } \\
\text { Taipei }\end{array}$ & Coinvestigator & $\begin{array}{l}\text { IGOS Country } \\
\text { Coordinator, led and } \\
\text { coordinated } \\
\text { communication } \\
\text { among sites, patient } \\
\text { inclusion, acquisition } \\
\text { of data }\end{array}$ \\
\hline $\begin{array}{l}\text { G. Chavada, } \\
\text { MD }\end{array}$ & $\begin{array}{l}\text { University of } \\
\text { Glasgow, UK }\end{array}$ & Coinvestigator & $\begin{array}{l}\text { IGOS Country } \\
\text { Coordinator, led and } \\
\text { coordinated } \\
\text { communication } \\
\text { among sites, patient } \\
\text { inclusion, acquisition } \\
\text { of data }\end{array}$ \\
\hline
\end{tabular}

Appendix 2 (continued)

\begin{tabular}{|c|c|c|c|}
\hline Name & Location & Role & Contribution \\
\hline $\begin{array}{l}\text { J.M. } \\
\text { Addington, } \\
\text { MD }\end{array}$ & $\begin{array}{l}\text { University of } \\
\text { Virginia, } \\
\text { Charlottesville }\end{array}$ & Coinvestigator & $\begin{array}{l}\text { Patient inclusion, } \\
\text { acquisition of data }\end{array}$ \\
\hline $\begin{array}{l}\text { S. Ajroud- } \\
\text { Driss, MD }\end{array}$ & $\begin{array}{l}\text { Northwestern } \\
\text { University } \\
\text { Feinberg, } \\
\text { Chicago, IL }\end{array}$ & Coinvestigator & $\begin{array}{l}\text { Patient inclusion, } \\
\text { acquisition of data }\end{array}$ \\
\hline $\begin{array}{l}\text { H. Andersen, } \\
\text { MD, PhD }\end{array}$ & $\begin{array}{l}\text { Aarhus } \\
\text { University } \\
\text { Hospital, } \\
\text { Denmark }\end{array}$ & Coinvestigator & $\begin{array}{l}\text { Patient inclusion, } \\
\text { acquisition of data }\end{array}$ \\
\hline $\begin{array}{l}\text { G. Antonini, } \\
\text { MD }\end{array}$ & $\begin{array}{l}\text { Department of } \\
\text { Neuroscience, } \\
\text { Mental Health } \\
\text { and Sensory } \\
\text { Organs } \\
\text { (NESMOS), } \\
\text { Sapienza } \\
\text { University, } \\
\text { Sant'Andrea } \\
\text { Hospital, } \\
\text { Rome, Italy }\end{array}$ & Coinvestigator & $\begin{array}{l}\text { Patient inclusion, } \\
\text { acquisition of data }\end{array}$ \\
\hline $\begin{array}{l}\text { A. Ariatti, } \\
\text { MD }\end{array}$ & $\begin{array}{l}\text { University } \\
\text { Hospital of } \\
\text { Modena, Italy }\end{array}$ & Coinvestigator & $\begin{array}{l}\text { Patient inclusion, } \\
\text { acquisition of data }\end{array}$ \\
\hline $\begin{array}{l}\text { S. Attarian, } \\
\text { MD PhD }\end{array}$ & $\begin{array}{l}\text { CHU Timone, } \\
\text { Marseille, } \\
\text { France }\end{array}$ & Coinvestigator & $\begin{array}{l}\text { Patient inclusion, } \\
\text { acquisition of data }\end{array}$ \\
\hline $\begin{array}{l}\text { U.A. } \\
\text { Badrising, } \\
\text { MD, PhD }\end{array}$ & $\begin{array}{l}\text { Leiden } \\
\text { University } \\
\text { Medical } \\
\text { Centre, the } \\
\text { Netherlands }\end{array}$ & Coinvestigator & $\begin{array}{l}\text { Patient inclusion, } \\
\text { acquisition of data }\end{array}$ \\
\hline $\begin{array}{l}\text { F.A. Barroso, } \\
\text { MD }\end{array}$ & $\begin{array}{l}\text { Instituto de } \\
\text { Investigaciones } \\
\text { Neurológicas } \\
\text { Raúl Carrea, } \\
\text { FLENI, Buenos } \\
\text { Aires, } \\
\text { Argentina }\end{array}$ & Coinvestigator & $\begin{array}{l}\text { Patient inclusion, } \\
\text { acquisition of data }\end{array}$ \\
\hline $\begin{array}{l}\text { L. Benedetti, } \\
\text { MD, PhD }\end{array}$ & $\begin{array}{l}\text { Ospedale } \\
\text { Sant'Andrea } \\
\text { La Spezia, Italy }\end{array}$ & Coinvestigator & $\begin{array}{l}\text { Patient inclusion, } \\
\text { acquisition of data }\end{array}$ \\
\hline $\begin{array}{l}\text { A. Beronio, } \\
\text { MD }\end{array}$ & $\begin{array}{l}\text { Ospedale } \\
\text { Sant'Andrea } \\
\text { La Spezia, Italy }\end{array}$ & Coinvestigator & $\begin{array}{l}\text { Patient inclusion, } \\
\text { acquisition of data }\end{array}$ \\
\hline $\begin{array}{l}\text { M. Bianco, } \\
\text { MD }\end{array}$ & $\begin{array}{l}\text { Milan } \\
\text { University, } \\
\text { Humanitas } \\
\text { Clinicala and } \\
\text { Research } \\
\text { Institute Milan, } \\
\text { Italy }\end{array}$ & Coinvestigator & $\begin{array}{l}\text { Patient inclusion, } \\
\text { acquisition of data }\end{array}$ \\
\hline D. Binda, MD & $\begin{array}{l}\text { Valduce } \\
\text { Hospital, } \\
\text { Como; } \\
\text { University of } \\
\text { Milano- } \\
\text { Bicocca, } \\
\text { Monza, Italy }\end{array}$ & Coinvestigator & $\begin{array}{l}\text { Patient inclusion, } \\
\text { acquisition of data }\end{array}$ \\
\hline C. Briani, MD & $\begin{array}{l}\text { University of } \\
\text { Padova, Italy }\end{array}$ & Coinvestigator & $\begin{array}{l}\text { Patient inclusion, } \\
\text { acquisition of data }\end{array}$ \\
\hline
\end{tabular}

Continued 
Appendix 2 (continued)

\begin{tabular}{|c|c|c|c|}
\hline Name & Location & Role & Contribution \\
\hline $\begin{array}{l}\text { C. } \\
\text { Bunschoten, } \\
\text { MD }\end{array}$ & $\begin{array}{l}\text { Erasmus } \\
\text { University } \\
\text { Medical } \\
\text { Centre, } \\
\text { Rotterdam, the } \\
\text { Netherlands }\end{array}$ & Coinvestigator & $\begin{array}{l}\text { Patient inclusion, } \\
\text { acquisition of data }\end{array}$ \\
\hline $\begin{array}{l}\text { J. Bürmann, } \\
\text { MD }\end{array}$ & $\begin{array}{l}\text { Universitäts- } \\
\text { klinikum des } \\
\text { Saarlandes, } \\
\text { Homburg, } \\
\text { Germany }\end{array}$ & Coinvestigator & $\begin{array}{l}\text { Patient inclusion, } \\
\text { acquisition of data }\end{array}$ \\
\hline $\begin{array}{l}\text { I.R. Bella, } \\
\text { MD }\end{array}$ & $\begin{array}{l}\text { University of } \\
\text { Massachusetts } \\
\text { Medical } \\
\text { School, } \\
\text { Worcester }\end{array}$ & Coinvestigator & $\begin{array}{l}\text { Patient inclusion, } \\
\text { acquisition of data }\end{array}$ \\
\hline $\begin{array}{l}\text { T.E. } \\
\text { Bertorini, } \\
\text { MD }\end{array}$ & $\begin{array}{l}\text { The University } \\
\text { of Tennessee } \\
\text { Health } \\
\text { Science } \\
\text { Center } \\
\text { (UTHSC), } \\
\text { Memphis }\end{array}$ & Coinvestigator & $\begin{array}{l}\text { Patient inclusion, } \\
\text { acquisition of data }\end{array}$ \\
\hline $\begin{array}{l}\text { R. } \\
\text { Bhavaraju- } \\
\text { Sanka, MD }\end{array}$ & $\begin{array}{l}\text { University } \\
\text { Hospital/ } \\
\text { University of } \\
\text { Texas Health } \\
\text { Science } \\
\text { Center, San } \\
\text { Antonio }\end{array}$ & Coinvestigator & $\begin{array}{l}\text { Patient inclusion, } \\
\text { acquisition of data }\end{array}$ \\
\hline $\begin{array}{l}\text { T.H. } \\
\text { Brannagan, } \\
\text { MD }\end{array}$ & $\begin{array}{l}\text { Columbia } \\
\text { University, } \\
\text { New York, NY }\end{array}$ & Coinvestigator & $\begin{array}{l}\text { Patient inclusion, } \\
\text { acquisition of data }\end{array}$ \\
\hline $\begin{array}{l}\text { M. Busby, } \\
\text { MD }\end{array}$ & $\begin{array}{l}\text { Leeds General } \\
\text { Infirmary, } \\
\text { Bradford, UK }\end{array}$ & Coinvestigator & $\begin{array}{l}\text { Patient inclusion, } \\
\text { acquisition of data }\end{array}$ \\
\hline $\begin{array}{l}\text { S. } \\
\text { Butterworth, } \\
\text { MD }\end{array}$ & $\begin{array}{l}\text { Pinderfields } \\
\text { Hospital, } \\
\text { Wakefield, UK }\end{array}$ & Coinvestigator & $\begin{array}{l}\text { Patient inclusion, } \\
\text { acquisition of data }\end{array}$ \\
\hline $\begin{array}{l}\text { C. } \\
\text { Casasnovas, } \\
\text { MD, PhD }\end{array}$ & $\begin{array}{l}\text { Bellvitge } \\
\text { University } \\
\text { Hospital } \\
\text { Neurologic } \\
\text { Diseases and } \\
\text { Neurogenetics } \\
\text { Group; } \\
\text { Bellvitge } \\
\text { Biomedical } \\
\text { Research } \\
\text { Institute } \\
\text { (IDIBELL); } \\
\text { Faculty of } \\
\text { Medicine, } \\
\text { University of } \\
\text { Barcelona, } \\
\text { Spain }\end{array}$ & Coinvestigator & $\begin{array}{l}\text { Patient inclusion, } \\
\text { acquisition of data }\end{array}$ \\
\hline $\begin{array}{l}\text { G. Cavaletti, } \\
\text { MD }\end{array}$ & $\begin{array}{l}\text { University } \\
\text { Milano- } \\
\text { Bicocca, } \\
\text { Monza, Italy }\end{array}$ & Coinvestigator & $\begin{array}{l}\text { Patient inclusion, } \\
\text { acquisition of data }\end{array}$ \\
\hline $\begin{array}{l}\text { C.C. Chao, } \\
\text { MD, PhD }\end{array}$ & $\begin{array}{l}\text { National } \\
\text { Taiwan } \\
\text { University } \\
\text { Hospital, } \\
\text { Taipei }\end{array}$ & Coinvestigator & $\begin{array}{l}\text { Patient inclusion, } \\
\text { acquisition of data }\end{array}$ \\
\hline
\end{tabular}

Appendix 2 (continued)

\begin{tabular}{|c|c|c|c|}
\hline Name & Location & Role & Contribution \\
\hline $\begin{array}{l}\text { S. Chen, MD, } \\
\text { PhD }\end{array}$ & $\begin{array}{l}\text { Rutgers, } \\
\text { Robert Wood } \\
\text { Johnson } \\
\text { University } \\
\text { Hospital, New } \\
\text { Brunswick, NJ }\end{array}$ & Coinvestigator & $\begin{array}{l}\text { Patient inclusion, } \\
\text { acquisition of data }\end{array}$ \\
\hline $\begin{array}{l}\text { S. Chetty, } \\
\text { MD }\end{array}$ & $\begin{array}{l}\text { Groote Schuur } \\
\text { Hospital, } \\
\text { University of } \\
\text { Cape Town, } \\
\text { South Africa }\end{array}$ & Coinvestigator & $\begin{array}{l}\text { Patient inclusion, } \\
\text { acquisition of data }\end{array}$ \\
\hline $\begin{array}{l}\text { K.G. Claeys, } \\
\text { MD, PhD }\end{array}$ & $\begin{array}{l}\text { University } \\
\text { Hospitals } \\
\text { Leuven; KU } \\
\text { Leuven, } \\
\text { Belgium }\end{array}$ & Coinvestigator & $\begin{array}{l}\text { Patient inclusion, } \\
\text { acquisition of data }\end{array}$ \\
\hline $\begin{array}{l}\text { M.E. Conti, } \\
\text { MD }\end{array}$ & $\begin{array}{l}\text { University } \\
\text { Hospital } \\
\text { Clinicas, } \\
\text { Buenos Aires, } \\
\text { Argentina }\end{array}$ & Coinvestigator & $\begin{array}{l}\text { Patient inclusion, } \\
\text { acquisition of data }\end{array}$ \\
\hline $\begin{array}{l}\text { J.S. } \\
\text { Cosgrove, } \\
\text { MD }\end{array}$ & $\begin{array}{l}\text { Leeds General } \\
\text { Infirmary, UK }\end{array}$ & Coinvestigator & $\begin{array}{l}\text { Patient inclusion, } \\
\text { acquisition of data }\end{array}$ \\
\hline $\begin{array}{l}\text { M.C. } \\
\text { Dalakas, MD }\end{array}$ & $\begin{array}{l}\text { Thomas } \\
\text { Jefferson } \\
\text { University, } \\
\text { Philadelphia, } \\
\text { PA; National } \\
\text { and } \\
\text { Kapodistrian } \\
\text { University of } \\
\text { Athens, Greece }\end{array}$ & Coinvestigator & $\begin{array}{l}\text { Patient inclusion, } \\
\text { acquisition of data }\end{array}$ \\
\hline $\begin{array}{l}\text { C. } \\
\text { Demichelis, } \\
\text { MD }\end{array}$ & $\begin{array}{l}\text { University of } \\
\text { Genova, Italy }\end{array}$ & Coinvestigator & $\begin{array}{l}\text { Patient inclusion, } \\
\text { acquisition of data }\end{array}$ \\
\hline $\begin{array}{l}\text { M.A. } \\
\text { Derejko, } \\
\text { MD, PhD }\end{array}$ & $\begin{array}{l}\text { Odense } \\
\text { University } \\
\text { Hospital, } \\
\text { Denmark }\end{array}$ & Coinvestigator & $\begin{array}{l}\text { Patient inclusion, } \\
\text { acquisition of data }\end{array}$ \\
\hline $\begin{array}{l}\text { U. Dillmann, } \\
\text { MD }\end{array}$ & $\begin{array}{l}\text { Universität- } \\
\text { sklinikum des } \\
\text { Saarlandes, } \\
\text { Homburg, } \\
\text { Germany }\end{array}$ & Coinvestigator & $\begin{array}{l}\text { Patient inclusion, } \\
\text { acquisition of data }\end{array}$ \\
\hline $\begin{array}{l}\text { M.M. } \\
\text { Dimachkie, } \\
\text { MD }\end{array}$ & $\begin{array}{l}\text { University of } \\
\text { Kansas } \\
\text { Medical } \\
\text { Center, } \\
\text { Kansas City }\end{array}$ & Coinvestigator & $\begin{array}{l}\text { Patient inclusion, } \\
\text { acquisition of data }\end{array}$ \\
\hline $\begin{array}{l}\text { K. Doppler, } \\
\text { MD }\end{array}$ & $\begin{array}{l}\text { Universität- } \\
\text { sklinikum } \\
\text { Würzburg, } \\
\text { Germany }\end{array}$ & Coinvestigator & $\begin{array}{l}\text { Patient inclusion, } \\
\text { acquisition of data }\end{array}$ \\
\hline $\begin{array}{l}\text { C. } \\
\text { Dornonville } \\
\text { de la Cour, } \\
\text { MD }\end{array}$ & $\begin{array}{l}\text { National } \\
\text { Hospital } \\
\text { Copenhagen, } \\
\text { Denmark }\end{array}$ & Coinvestigator & $\begin{array}{l}\text { Patient inclusion, } \\
\text { acquisition of data }\end{array}$ \\
\hline $\begin{array}{l}\text { A. Echaniz- } \\
\text { Laguna, MD }\end{array}$ & $\begin{array}{l}\text { Hopital de } \\
\text { Hautepierre, } \\
\text { Strasbourgh, } \\
\text { France }\end{array}$ & Coinvestigator & $\begin{array}{l}\text { Patient inclusion, } \\
\text { acquisition of data }\end{array}$ \\
\hline
\end{tabular}


Appendix 2 (continued)

\begin{tabular}{|c|c|c|c|}
\hline Name & Location & Role & Contribution \\
\hline $\begin{array}{l}\text { F. Eftimov, } \\
\text { MD, PhD }\end{array}$ & $\begin{array}{l}\text { Amsterdam } \\
\text { UMC, } \\
\text { University of } \\
\text { Amsterdam, } \\
\text { Amsterdam } \\
\text { Neuroscience } \\
\text { Institute, the } \\
\text { Netherlands }\end{array}$ & Coinvestigator & $\begin{array}{l}\text { Patient inclusion, } \\
\text { acquisition of data }\end{array}$ \\
\hline $\begin{array}{l}\text { C.G. Faber, } \\
\text { MD, PhD }\end{array}$ & $\begin{array}{l}\text { Maastricht } \\
\text { University } \\
\text { Medical } \\
\text { Centre, the } \\
\text { Netherlands }\end{array}$ & Coinvestigator & $\begin{array}{l}\text { Patient inclusion, } \\
\text { acquisition of data }\end{array}$ \\
\hline R. Fazio, MD & $\begin{array}{l}\text { Scientific } \\
\text { Institute San } \\
\text { Raffaele, } \\
\text { Milan, Italy }\end{array}$ & Coinvestigator & $\begin{array}{l}\text { Patient inclusion, } \\
\text { acquisition of data }\end{array}$ \\
\hline C. Fokke, MD & $\begin{array}{l}\text { Gelre } \\
\text { Hospital, } \\
\text { Zutphen and } \\
\text { Apeldoorn, } \\
\text { the } \\
\text { Netherlands }\end{array}$ & Coinvestigator & $\begin{array}{l}\text { Patient inclusion, } \\
\text { acquisition of data }\end{array}$ \\
\hline $\begin{array}{l}\text { T. Fujioka, } \\
\text { MD }\end{array}$ & $\begin{array}{l}\text { Toho } \\
\text { University } \\
\text { Medical } \\
\text { Center, Japan }\end{array}$ & Coinvestigator & $\begin{array}{l}\text { Patient inclusion, } \\
\text { acquisition of data }\end{array}$ \\
\hline $\begin{array}{l}\text { E.A. } \\
\text { Fulgenzi, MD }\end{array}$ & $\begin{array}{l}\text { Hospital } \\
\text { Cesar Milstein } \\
\text { Buenos Aires, } \\
\text { Argentina }\end{array}$ & Coinvestigator & $\begin{array}{l}\text { Patient inclusion, } \\
\text { acquisition of data }\end{array}$ \\
\hline $\begin{array}{l}\text { T. Garcia- } \\
\text { Sobrino, MD }\end{array}$ & $\begin{array}{l}\text { Hospital } \\
\text { Clínico de } \\
\text { Santiago, } \\
\text { Santiago de } \\
\text { Compostela } \\
\text { (A Coruña), } \\
\text { Spain }\end{array}$ & Coinvestigator & $\begin{array}{l}\text { Patient inclusion, } \\
\text { acquisition of data }\end{array}$ \\
\hline $\begin{array}{l}\text { M.P.J. } \\
\text { Garssen, } \\
\text { MD, PhD }\end{array}$ & $\begin{array}{l}\text { Jeroen Bosch } \\
\text { Hospital's } \\
\text { Hertogen- } \\
\text { bosch, } \\
\text { Zaltbommel } \\
\text { and Drunen, } \\
\text { the } \\
\text { Netherlands }\end{array}$ & Coinvestigator & $\begin{array}{l}\text { Patient inclusion, } \\
\text { acquisition of data }\end{array}$ \\
\hline $\begin{array}{l}\text { H.M. } \\
\text { Georgios, } \\
\text { MD }\end{array}$ & $\begin{array}{l}\text { University of } \\
\text { Thessaly, } \\
\text { Hospital of } \\
\text { Larissa, } \\
\text { Greece; } \\
\text { Medical } \\
\text { School, } \\
\text { University of } \\
\text { Cyprus, } \\
\text { Nicosia }\end{array}$ & Coinvestigator & $\begin{array}{l}\text { Patient inclusion, } \\
\text { acquisition of data }\end{array}$ \\
\hline $\begin{array}{l}\text { C.J. Gijsbers, } \\
\text { MD }\end{array}$ & $\begin{array}{l}\text { Vlietland } \\
\text { Hospital, } \\
\text { Schiedam, the } \\
\text { Netherlands }\end{array}$ & Coinvestigator & $\begin{array}{l}\text { Patient inclusion, } \\
\text { acquisition of data }\end{array}$ \\
\hline $\begin{array}{l}\text { J.M. } \\
\text { Gilchrist, } \\
\text { MD }\end{array}$ & $\begin{array}{l}\text { Southern } \\
\text { Illinois } \\
\text { University } \\
\text { School of } \\
\text { Medicine, } \\
\text { Springfield }\end{array}$ & Coinvestigator & $\begin{array}{l}\text { Patient inclusion, } \\
\text { acquisition of data }\end{array}$ \\
\hline
\end{tabular}

Appendix 2 (continued)

\begin{tabular}{|c|c|c|c|}
\hline Name & Location & Role & Contribution \\
\hline $\begin{array}{l}\text { J. Gilhuis, } \\
\text { MD }\end{array}$ & $\begin{array}{l}\text { Reinier de } \\
\text { Graaf } \\
\text { Gasthuis, } \\
\text { Delft, the } \\
\text { Netherlands }\end{array}$ & Coinvestigator & $\begin{array}{l}\text { Patient inclusion, } \\
\text { acquisition of data }\end{array}$ \\
\hline E. Giorli, MD & $\begin{array}{l}\text { Ospedale } \\
\text { Sant'Andrea } \\
\text { La Spezia, Italy }\end{array}$ & Coinvestigator & $\begin{array}{l}\text { Patient inclusion, } \\
\text { acquisition of data }\end{array}$ \\
\hline $\begin{array}{l}\text { J.M. } \\
\text { Goldstein, } \\
\text { MD }\end{array}$ & $\begin{array}{l}\text { Neurology, } \\
\text { Neuro- } \\
\text { muscular } \\
\text { Diseases, } \\
\text { Electromyo- } \\
\text { graphy, } \\
\text { Hospital for } \\
\text { Special } \\
\text { Surgery, New } \\
\text { York; Weill } \\
\text { Medical } \\
\text { College of } \\
\text { Cornell } \\
\text { University, } \\
\text { New York, NY }\end{array}$ & Coinvestigator & $\begin{array}{l}\text { Patient inclusion, } \\
\text { acquisition of data }\end{array}$ \\
\hline $\begin{array}{l}\text { N.A. Goyal, } \\
\text { MD }\end{array}$ & $\begin{array}{l}\text { University of } \\
\text { California, } \\
\text { Irvine }\end{array}$ & Coinvestigator & $\begin{array}{l}\text { Patient inclusion, } \\
\text { acquisition of data }\end{array}$ \\
\hline $\begin{array}{l}\text { V. Granit, } \\
\text { MD }\end{array}$ & $\begin{array}{l}\text { Montefiore } \\
\text { Medical } \\
\text { Center, New } \\
\text { York, NY }\end{array}$ & Coinvestigator & $\begin{array}{l}\text { Patient inclusion, } \\
\text { acquisition of data }\end{array}$ \\
\hline $\begin{array}{l}\text { A. } \\
\text { Grapperon, } \\
\text { MD }\end{array}$ & $\begin{array}{l}\text { CHU Timone, } \\
\text { Marseille, } \\
\text { France }\end{array}$ & Coinvestigator & $\begin{array}{l}\text { Patient inclusion, } \\
\text { acquisition of data }\end{array}$ \\
\hline $\begin{array}{l}\text { G. Gutiérrez, } \\
\text { MD }\end{array}$ & $\begin{array}{l}\text { Hospital } \\
\text { Universitario } \\
\text { Infanta Sofia, } \\
\text { San } \\
\text { Sebastian, } \\
\text { Spain }\end{array}$ & Coinvestigator & $\begin{array}{l}\text { Patient inclusion, } \\
\text { acquisition of data }\end{array}$ \\
\hline $\begin{array}{l}\text { R.D.M. } \\
\text { Hadden, MD, } \\
\text { PhD }\end{array}$ & $\begin{array}{l}\text { King's College } \\
\text { Hospital, } \\
\text { London, UK }\end{array}$ & Coinvestigator & $\begin{array}{l}\text { Patient inclusion, } \\
\text { acquisition of data }\end{array}$ \\
\hline $\begin{array}{l}\text { J.V. Holbech, } \\
\text { PhD }\end{array}$ & $\begin{array}{l}\text { Odense } \\
\text { University } \\
\text { Hospital, } \\
\text { Denmark }\end{array}$ & Coinvestigator & $\begin{array}{l}\text { Patient inclusion, } \\
\text { acquisition of data }\end{array}$ \\
\hline $\begin{array}{l}\text { J.K.L. Holt, } \\
\text { PhD, FRCP }\end{array}$ & $\begin{array}{l}\text { The Walton } \\
\text { Centre, } \\
\text { Liverpool, UK }\end{array}$ & Coinvestigator & $\begin{array}{l}\text { Patient inclusion, } \\
\text { acquisition of data }\end{array}$ \\
\hline $\begin{array}{l}\text { C. Homedes } \\
\text { Pedret, MD }\end{array}$ & $\begin{array}{l}\text { Bellvitge } \\
\text { University } \\
\text { Hospital, } \\
\text { Barcelona, } \\
\text { Spain }\end{array}$ & Coinvestigator & $\begin{array}{l}\text { Patient inclusion, } \\
\text { acquisition of data }\end{array}$ \\
\hline M. Htut, MD & $\begin{array}{l}\text { St. George's } \\
\text { Hospital, } \\
\text { London, UK }\end{array}$ & Coinvestigator & $\begin{array}{l}\text { Patient inclusion, } \\
\text { acquisition of data }\end{array}$ \\
\hline $\begin{array}{l}\text { K. Jellema, } \\
\text { MD, PhD }\end{array}$ & $\begin{array}{l}\text { Haaglanden } \\
\text { Medisch } \\
\text { Centrum, The } \\
\text { Hague, the } \\
\text { Netherlands }\end{array}$ & Coinvestigator & $\begin{array}{l}\text { Patient inclusion, } \\
\text { acquisition of data }\end{array}$ \\
\hline
\end{tabular}

Continued 
Appendix 2 (continued)

\begin{tabular}{|c|c|c|c|}
\hline Name & Location & Role & Contribution \\
\hline $\begin{array}{l}\text { I. Jericó } \\
\text { Pascual, MD, } \\
\text { PhD }\end{array}$ & $\begin{array}{l}\text { Complejo } \\
\text { Hospitalario } \\
\text { de Navarra, } \\
\text { Pamplona, } \\
\text { Spain }\end{array}$ & Coinvestigator & $\begin{array}{l}\text { Patient inclusion, } \\
\text { acquisition of data }\end{array}$ \\
\hline $\begin{array}{l}\text { M.C. Jimeno- } \\
\text { Montero, } \\
\text { research } \\
\text { nurse }\end{array}$ & $\begin{array}{l}\text { Hospital } \\
\text { Universitario } \\
\text { Infanta Sofia, } \\
\text { San } \\
\text { Sebastian, } \\
\text { Spain }\end{array}$ & Coinvestigator & $\begin{array}{l}\text { Patient inclusion, } \\
\text { acquisition of data }\end{array}$ \\
\hline $\begin{array}{l}\text { K. Kaida, } \\
\text { MD, PhD }\end{array}$ & $\begin{array}{l}\text { National } \\
\text { Defense } \\
\text { Medical } \\
\text { College, } \\
\text { Saitama, } \\
\text { Japan }\end{array}$ & Coinvestigator & $\begin{array}{l}\text { Patient inclusion, } \\
\text { acquisition of data }\end{array}$ \\
\hline $\begin{array}{l}\text { S. Karafiath, } \\
\text { MD }\end{array}$ & $\begin{array}{l}\text { University of } \\
\text { Utah School of } \\
\text { Medicine, Salt } \\
\text { Lake City }\end{array}$ & Coinvestigator & $\begin{array}{l}\text { Patient inclusion, } \\
\text { acquisition of data }\end{array}$ \\
\hline $\begin{array}{l}\text { H.D. } \\
\text { Katzberg, } \\
\text { MD }\end{array}$ & $\begin{array}{l}\text { University of } \\
\text { Toronto, } \\
\text { Canada }\end{array}$ & Coinvestigator & $\begin{array}{l}\text { Patient inclusion, } \\
\text { acquisition of data }\end{array}$ \\
\hline L. Kiers, MD & $\begin{array}{l}\text { The Royal } \\
\text { Melbourne } \\
\text { Hospital, } \\
\text { Parkville, } \\
\text { Australia }\end{array}$ & Coinvestigator & $\begin{array}{l}\text { Patient inclusion, } \\
\text { acquisition of data }\end{array}$ \\
\hline $\begin{array}{l}\text { B.C. Kieseier, } \\
\text { MD }\end{array}$ & $\begin{array}{l}\text { Heinrich } \\
\text { Heine } \\
\text { University, } \\
\text { Düsseldorf, } \\
\text { Germany }\end{array}$ & Coinvestigator & $\begin{array}{l}\text { Patient inclusion, } \\
\text { acquisition of data }\end{array}$ \\
\hline $\begin{array}{l}\text { K. } \\
\text { Kimpinski, } \\
\text { MD }\end{array}$ & $\begin{array}{l}\text { University } \\
\text { Hospital, } \\
\text { LHSC, } \\
\text { London- } \\
\text { Ontario, } \\
\text { Canada }\end{array}$ & Coinvestigator & $\begin{array}{l}\text { Patient inclusion, } \\
\text { acquisition of data }\end{array}$ \\
\hline $\begin{array}{l}\text { R.P. } \\
\text { Kleyweg, } \\
\text { MD, PhD }\end{array}$ & $\begin{array}{l}\text { Albert } \\
\text { Schweitzer } \\
\text { Hospital, } \\
\text { Dordrecht, } \\
\text { the } \\
\text { Netherlands }\end{array}$ & Coinvestigator & $\begin{array}{l}\text { Patient inclusion, } \\
\text { acquisition of data }\end{array}$ \\
\hline $\begin{array}{l}\text { N. Kokubun, } \\
\text { MD }\end{array}$ & $\begin{array}{l}\text { Dokkyo } \\
\text { Medical } \\
\text { University, } \\
\text { Tochigi, Japan }\end{array}$ & Coinvestigator & $\begin{array}{l}\text { Patient inclusion, } \\
\text { acquisition of data }\end{array}$ \\
\hline $\begin{array}{l}\text { N.A. Kolb, } \\
\text { MD }\end{array}$ & $\begin{array}{l}\text { University of } \\
\text { Vermont, } \\
\text { Burlington }\end{array}$ & Coinvestigator & $\begin{array}{l}\text { Patient inclusion, } \\
\text { acquisition of data }\end{array}$ \\
\hline $\begin{array}{l}\text { K. } \\
\text { Kuitwaard, } \\
\text { MD, PhD }\end{array}$ & $\begin{array}{l}\text { Albert } \\
\text { Schweitzer } \\
\text { Hospital, } \\
\text { Dordrecht, } \\
\text { the } \\
\text { Netherlands }\end{array}$ & Coinvestigator & $\begin{array}{l}\text { Patient inclusion, } \\
\text { acquisition of data }\end{array}$ \\
\hline $\begin{array}{l}\text { S. } \\
\text { Kuwabara, } \\
\text { MD, PhD }\end{array}$ & $\begin{array}{l}\text { Chiba } \\
\text { University, } \\
\text { Japan }\end{array}$ & Coinvestigator & $\begin{array}{l}\text { Patient inclusion, } \\
\text { acquisition of data }\end{array}$ \\
\hline
\end{tabular}

Appendix 2 (continued)

\begin{tabular}{|c|c|c|c|}
\hline Name & Location & Role & Contribution \\
\hline $\begin{array}{l}\text { J.Y. Kwan, } \\
\text { MD }\end{array}$ & $\begin{array}{l}\text { University of } \\
\text { Maryland } \\
\text { School of } \\
\text { Medicine, } \\
\text { Baltimore }\end{array}$ & Coinvestigator & $\begin{array}{l}\text { Patient inclusion, } \\
\text { acquisition of data }\end{array}$ \\
\hline $\begin{array}{l}\text { S.S. Ladha, } \\
\text { MD }\end{array}$ & $\begin{array}{l}\text { Barrow } \\
\text { Neurology } \\
\text { Clinics, } \\
\text { Phoenix, AZ }\end{array}$ & Coinvestigator & $\begin{array}{l}\text { Patient inclusion, } \\
\text { acquisition of data }\end{array}$ \\
\hline $\begin{array}{l}\text { L. } \\
\text { Landschoff } \\
\text { Lassen, MD }\end{array}$ & $\begin{array}{l}\text { Glostrup } \\
\text { Hospital, } \\
\text { Denmark }\end{array}$ & Coinvestigator & $\begin{array}{l}\text { Patient inclusion, } \\
\text { acquisition of data }\end{array}$ \\
\hline $\begin{array}{l}\text { V. Lawson, } \\
\text { MD }\end{array}$ & $\begin{array}{l}\text { Wexner } \\
\text { Medical } \\
\text { Center at The } \\
\text { Ohio State } \\
\text { University, } \\
\text { Columbus }\end{array}$ & Coinvestigator & $\begin{array}{l}\text { Patient inclusion, } \\
\text { acquisition of data }\end{array}$ \\
\hline $\begin{array}{l}\text { D. } \\
\text { Ledingham, } \\
\text { MD }\end{array}$ & $\begin{array}{l}\text { Royal Victoria } \\
\text { Infirmary, } \\
\text { Newcastle } \\
\text { upon Tyne } \\
\text { Hospitals NHS } \\
\text { Foundation } \\
\text { Trust, } \\
\text { Newcastle, UK }\end{array}$ & Coinvestigator & $\begin{array}{l}\text { Patient inclusion, } \\
\text { acquisition of data }\end{array}$ \\
\hline $\begin{array}{l}\text { S.T. Lucy, } \\
\text { research } \\
\text { project } \\
\text { assistant }\end{array}$ & $\begin{array}{l}\text { University of } \\
\text { Vermont } \\
\text { Medical } \\
\text { Center, } \\
\text { Burlington }\end{array}$ & Coinvestigator & $\begin{array}{l}\text { Patient inclusion, } \\
\text { acquisition of data }\end{array}$ \\
\hline $\begin{array}{l}\text { M.P.T. Lunn, } \\
\text { MD, PhD }\end{array}$ & $\begin{array}{l}\text { National } \\
\text { Hospital of } \\
\text { Neurology and } \\
\text { Neurosurgery, } \\
\text { London, UK }\end{array}$ & Coinvestigator & $\begin{array}{l}\text { Patient inclusion, } \\
\text { acquisition of data }\end{array}$ \\
\hline $\begin{array}{l}\text { A. Magot, } \\
\text { MD }\end{array}$ & $\begin{array}{l}\text { Reference } \\
\text { Centre for } \\
\text { NMD, Nantes } \\
\text { University } \\
\text { Hospital, } \\
\text { France }\end{array}$ & Coinvestigator & $\begin{array}{l}\text { Patient inclusion, } \\
\text { acquisition of data }\end{array}$ \\
\hline $\begin{array}{l}\text { H. Manji, } \\
\text { MD, FRCP }\end{array}$ & $\begin{array}{l}\text { Ipswich } \\
\text { Hospital, UK }\end{array}$ & Coinvestigator & $\begin{array}{l}\text { Patient inclusion, } \\
\text { acquisition of } \\
\text { data }\end{array}$ \\
\hline $\begin{array}{l}\text { C. } \\
\text { Marchesoni, } \\
\text { MD }\end{array}$ & $\begin{array}{l}\text { Hospital } \\
\text { Britanico, } \\
\text { Buenos Aires, } \\
\text { Argentina }\end{array}$ & Coinvestigator & $\begin{array}{l}\text { Patient inclusion, } \\
\text { acquisition of data }\end{array}$ \\
\hline $\begin{array}{l}\text { G.A. Marfia, } \\
\text { MD }\end{array}$ & $\begin{array}{l}\text { Dysimmune } \\
\text { Neuropathies } \\
\text { unit, } \\
\text { Neurological } \\
\text { Clinic, } \\
\text { Policlinico Tor } \\
\text { Vergata, } \\
\text { Rome, Italy }\end{array}$ & Coinvestigator & $\begin{array}{l}\text { Patient inclusion, } \\
\text { acquisition of data }\end{array}$ \\
\hline $\begin{array}{l}\text { C. Márquez } \\
\text { Infante, MD }\end{array}$ & $\begin{array}{l}\text { Hospital } \\
\text { Universitario } \\
\text { Virgen del } \\
\text { Rocio, Seville, } \\
\text { Spain }\end{array}$ & Coinvestigator & $\begin{array}{l}\text { Patient inclusion, } \\
\text { acquisition of data }\end{array}$ \\
\hline
\end{tabular}


Appendix 2 (continued)

\begin{tabular}{|c|c|c|c|}
\hline Name & Location & Role & Contribution \\
\hline $\begin{array}{l}\text { E. Martinez } \\
\text { Hernandez, } \\
\text { MD }\end{array}$ & $\begin{array}{l}\text { Institut d'- } \\
\text { Investigacions } \\
\text { Biomédiques } \\
\text { August Pi i } \\
\text { Sunyer } \\
\text { (IDIBAPS), } \\
\text { Hospital Clinic, } \\
\text { Barcelona, } \\
\text { Spain }\end{array}$ & Coinvestigator & $\begin{array}{l}\text { Patient inclusion, } \\
\text { acquisition of data }\end{array}$ \\
\hline $\begin{array}{l}\text { G. Mataluni, } \\
\text { MD, PhD }\end{array}$ & $\begin{array}{l}\text { Dysimmune } \\
\text { Neuropathies } \\
\text { Unit, } \\
\text { Neurological } \\
\text { Clinic, } \\
\text { Policlinico Tor } \\
\text { Vergata, } \\
\text { Rome, Italy }\end{array}$ & Coinvestigator & $\begin{array}{l}\text { Patient inclusion, } \\
\text { acquisition of data }\end{array}$ \\
\hline $\begin{array}{l}\text { M. Mattiazi, } \\
\text { MD }\end{array}$ & $\begin{array}{l}\text { Hospital } \\
\text { Militar } \\
\text { Central, } \\
\text { Buenos Aires, } \\
\text { Argentina }\end{array}$ & Coinvestigator & $\begin{array}{l}\text { Patient inclusion, } \\
\text { acquisition of data }\end{array}$ \\
\hline $\begin{array}{l}\text { C.J. } \\
\text { MCDermott, } \\
\text { MD }\end{array}$ & $\begin{array}{l}\text { Royal } \\
\text { Hallamshire } \\
\text { Hospital, } \\
\text { NIHR Clinical } \\
\text { Research } \\
\text { Facility and } \\
\text { Biomedical } \\
\text { Research } \\
\text { Centre, } \\
\text { Sheffield, UK }\end{array}$ & Coinvestigator & $\begin{array}{l}\text { Patient inclusion, } \\
\text { acquisition of data }\end{array}$ \\
\hline $\begin{array}{l}\text { G.D. } \\
\text { Meekins, } \\
\text { MD }\end{array}$ & $\begin{array}{l}\text { University of } \\
\text { Minnesota } \\
\text { School of } \\
\text { Medicine, } \\
\text { Minneapolis }\end{array}$ & Coinvestigator & $\begin{array}{l}\text { Patient inclusion, } \\
\text { acquisition of data }\end{array}$ \\
\hline $\begin{array}{l}\text { J.A.L. Miller, } \\
\text { MD, PhD }\end{array}$ & $\begin{array}{l}\text { Royal Victoria } \\
\text { Infirmary, } \\
\text { Newcastle } \\
\text { upon Tyne } \\
\text { Hospitals NHS } \\
\text { Foundation } \\
\text { Trust, } \\
\text { Newcastle, UK }\end{array}$ & Coinvestigator & $\begin{array}{l}\text { Patient inclusion, } \\
\text { acquisition of data }\end{array}$ \\
\hline $\begin{array}{l}\text { G. Morís de } \\
\text { la Tassa, MD }\end{array}$ & $\begin{array}{l}\text { Hospital } \\
\text { Universitario } \\
\text { Central de } \\
\text { Asturias, } \\
\text { Spain }\end{array}$ & Coinvestigator & $\begin{array}{l}\text { Patient inclusion, } \\
\text { acquisition of data }\end{array}$ \\
\hline $\begin{array}{l}\text { J. Mozzoni, } \\
\text { physio } \\
\text {-therapist }\end{array}$ & $\begin{array}{l}\text { Hospital de } \\
\text { Pediatría J.P. } \\
\text { Garrahan, } \\
\text { Buenos Aires, } \\
\text { Argentina }\end{array}$ & Coinvestigator & $\begin{array}{l}\text { Patient inclusion, } \\
\text { acquisition of data }\end{array}$ \\
\hline $\begin{array}{l}\text { C. } \\
\text { Nascimbene, } \\
\text { MD, PhD }\end{array}$ & $\begin{array}{l}\text { Luigi Sacco } \\
\text { Hospital, } \\
\text { Milan, Italy }\end{array}$ & Coinvestigator & $\begin{array}{l}\text { Patient inclusion, } \\
\text { acquisition of data }\end{array}$ \\
\hline $\begin{array}{l}\text { R.J. Nowak, } \\
\text { MD }\end{array}$ & $\begin{array}{l}\text { Yale } \\
\text { University } \\
\text { School of } \\
\text { Medicine, } \\
\text { New Haven, } \\
\text { CT }\end{array}$ & Coinvestigator & $\begin{array}{l}\text { Patient inclusion, } \\
\text { acquisition of data }\end{array}$ \\
\hline
\end{tabular}

Appendix 2 (continued)

\begin{tabular}{|c|c|c|c|}
\hline Name & Location & Role & Contribution \\
\hline $\begin{array}{l}\text { P. Orizaloa } \\
\text { Balaguer, } \\
\text { MD }\end{array}$ & $\begin{array}{l}\text { Hospital } \\
\text { Universitario- } \\
\text { Marques de } \\
\text { Valdecilla, } \\
\text { Santander, } \\
\text { Cantabria, } \\
\text { Spain }\end{array}$ & Coinvestigator & $\begin{array}{l}\text { Patient inclusion, } \\
\text { acquisition of data }\end{array}$ \\
\hline $\begin{array}{l}\text { M. Osei- } \\
\text { Bonsu, MD }\end{array}$ & $\begin{array}{l}\text { James Cook } \\
\text { University } \\
\text { Hospital, } \\
\text { Middles- } \\
\text { brough, UK }\end{array}$ & Coinvestigator & $\begin{array}{l}\text { Patient inclusion, } \\
\text { acquisition of data }\end{array}$ \\
\hline $\begin{array}{l}\text { E.B. Lee Pan, } \\
\text { MD }\end{array}$ & $\begin{array}{l}\text { Groote } \\
\text { Schuur } \\
\text { Hospital, } \\
\text { University of } \\
\text { Cape Town, } \\
\text { South Africa }\end{array}$ & Coinvestigator & $\begin{array}{l}\text { Patient inclusion, } \\
\text { acquisition of data }\end{array}$ \\
\hline $\begin{array}{l}\text { A.M. Pardal, } \\
\text { MD }\end{array}$ & $\begin{array}{l}\text { Hospital } \\
\text { Britanico, } \\
\text { Buenos Aires, } \\
\text { Argentina }\end{array}$ & Coinvestigator & $\begin{array}{l}\text { Patient inclusion, } \\
\text { acquisition of data }\end{array}$ \\
\hline $\begin{array}{l}\text { J. Pardo, MD, } \\
\text { PhD }\end{array}$ & $\begin{array}{l}\text { Hospital } \\
\text { Clínico de } \\
\text { Santiago, } \\
\text { Santiago de } \\
\text { Compostela } \\
\text { (A Coruña), } \\
\text { Spain }\end{array}$ & Coinvestigator & $\begin{array}{l}\text { Patient inclusion, } \\
\text { acquisition of data }\end{array}$ \\
\hline $\begin{array}{l}\text { M. Pasnoor, } \\
\text { MD }\end{array}$ & $\begin{array}{l}\text { University of } \\
\text { Kansas } \\
\text { Medical } \\
\text { Center, } \\
\text { Kansas City }\end{array}$ & Coinvestigator & $\begin{array}{l}\text { Patient inclusion, } \\
\text { acquisition of data }\end{array}$ \\
\hline $\begin{array}{l}\text { M. Pulley, } \\
\text { MD }\end{array}$ & $\begin{array}{l}\text { University of } \\
\text { Florida, } \\
\text { Jacksonville }\end{array}$ & Coinvestigator & $\begin{array}{l}\text { Patient inclusion, } \\
\text { acquisition of data }\end{array}$ \\
\hline $\begin{array}{l}\text { Y.A. } \\
\text { Rajabally, } \\
\text { MD, PhD }\end{array}$ & $\begin{array}{l}\text { Queen } \\
\text { Elizabeth } \\
\text { Hospital, } \\
\text { Birmingham, } \\
\text { UK }\end{array}$ & Coinvestigator & $\begin{array}{l}\text { Patient inclusion, } \\
\text { acquisition of data }\end{array}$ \\
\hline $\begin{array}{l}\text { S. Rinaldi, } \\
\text { MBChB, PhD }\end{array}$ & $\begin{array}{l}\text { University of } \\
\text { Oxford \& } \\
\text { Oxford } \\
\text { University } \\
\text { Hospitals NHS } \\
\text { Foundation } \\
\text { Trust, UK }\end{array}$ & Coinvestigator & $\begin{array}{l}\text { Patient inclusion, } \\
\text { acquisition of data }\end{array}$ \\
\hline C. Ritter, MD & $\begin{array}{l}\text { University } \\
\text { Hospital of } \\
\text { Cologne, } \\
\text { Universität- } \\
\text { sklinikum Köln, } \\
\text { Cologne, } \\
\text { Germany }\end{array}$ & Coinvestigator & $\begin{array}{l}\text { Patient inclusion, } \\
\text { acquisition of data }\end{array}$ \\
\hline $\begin{array}{l}\text { R.C. Roberts, } \\
\text { MD }\end{array}$ & $\begin{array}{l}\text { Addenbrooke's } \\
\text { Hospital } \\
\text { Cambridge, } \\
\text { Cambridge, UK }\end{array}$ & Coinvestigator & $\begin{array}{l}\text { Patient inclusion, } \\
\text { acquisition of data }\end{array}$ \\
\hline $\begin{array}{l}\text { I. Rojas- } \\
\text { Marcos, MD }\end{array}$ & $\begin{array}{l}\text { Hospital } \\
\text { Univesitario } \\
\text { Reina Sofia, } \\
\text { Cordoba, Spain }\end{array}$ & Coinvestigator & $\begin{array}{l}\text { Patient inclusion, } \\
\text { acquisition of data }\end{array}$ \\
\hline
\end{tabular}

Continued 
Appendix 2 (continued)

\begin{tabular}{|c|c|c|c|}
\hline Name & Location & Role & Contribution \\
\hline $\begin{array}{l}\text { S.A. } \\
\text { Rudnicki, } \\
\text { MD }\end{array}$ & $\begin{array}{l}\text { University of } \\
\text { Arkansas, } \\
\text { Fayetteville }\end{array}$ & Coinvestigator & $\begin{array}{l}\text { Patient inclusion, } \\
\text { acquisition of data }\end{array}$ \\
\hline M. Ruiz, MD & $\begin{array}{l}\text { University of } \\
\text { Padova, Italy }\end{array}$ & Coinvestigator & $\begin{array}{l}\text { Patient inclusion, } \\
\text { acquisition of data }\end{array}$ \\
\hline $\begin{array}{l}\text { G.M. Sachs, } \\
\text { MD }\end{array}$ & $\begin{array}{l}\text { University of } \\
\text { Rhode Island, } \\
\text { Providence }\end{array}$ & Coinvestigator & $\begin{array}{l}\text { Patient inclusion, } \\
\text { acquisition of data }\end{array}$ \\
\hline $\begin{array}{l}\text { J.P.A. } \\
\text { Samijn, MD }\end{array}$ & $\begin{array}{l}\text { Maasstad } \\
\text { Hospital, } \\
\text { Rotterdam, } \\
\text { the } \\
\text { Netherlands }\end{array}$ & Coinvestigator & $\begin{array}{l}\text { Patient inclusion, } \\
\text { acquisition of data }\end{array}$ \\
\hline $\begin{array}{l}\text { L. Santoro, } \\
\text { MD, PhD }\end{array}$ & $\begin{array}{l}\text { University } \\
\text { Federico II, } \\
\text { Naples, Italy }\end{array}$ & Coinvestigator & $\begin{array}{l}\text { Patient inclusion, } \\
\text { acquisition of data }\end{array}$ \\
\hline $\begin{array}{l}\text { A. } \\
\text { Savransky, } \\
\text { MD }\end{array}$ & $\begin{array}{l}\text { Hospital de } \\
\text { Pediatría J.P. } \\
\text { Garrahan, } \\
\text { Buenos Aires, } \\
\text { Argentina }\end{array}$ & Coinvestigator & $\begin{array}{l}\text { Patient inclusion, } \\
\text { acquisition of data }\end{array}$ \\
\hline $\begin{array}{l}\text { A. Schenone, } \\
\text { MD, PhD }\end{array}$ & $\begin{array}{l}\text { Department of } \\
\text { Neuro- } \\
\text { sciences, } \\
\text { Rehabilitation, } \\
\text { Ophthal- } \\
\text { mology, } \\
\text { Genetics and } \\
\text { Maternal and } \\
\text { Infantile } \\
\text { Sciences } \\
\text { (DINOGMI), } \\
\text { University of } \\
\text { Genova; IRCCS } \\
\text { Policlinico San } \\
\text { Martino, } \\
\text { Genova, Italy }\end{array}$ & Coinvestigator & $\begin{array}{l}\text { Patient inclusion, } \\
\text { acquisition of data }\end{array}$ \\
\hline $\begin{array}{l}\text { L. } \\
\text { Schwindling, } \\
\text { MD }\end{array}$ & $\begin{array}{l}\text { Universität- } \\
\text { sklinikum des } \\
\text { Saarlandes, } \\
\text { Homburg, } \\
\text { Germany }\end{array}$ & Coinvestigator & $\begin{array}{l}\text { Patient inclusion, } \\
\text { acquisition of data }\end{array}$ \\
\hline $\begin{array}{l}\text { M.J. Sedano } \\
\text { Tous, MD }\end{array}$ & $\begin{array}{l}\text { Hospital } \\
\text { Universitario- } \\
\text { Marques de } \\
\text { Valdecilla, } \\
\text { Santander, } \\
\text { Cantabria, } \\
\text { Spain }\end{array}$ & Coinvestigator & $\begin{array}{l}\text { Patient inclusion, } \\
\text { acquisition of data }\end{array}$ \\
\hline $\begin{array}{l}\text { Y. Sekiguchi, } \\
\text { MD, PhD }\end{array}$ & $\begin{array}{l}\text { Chiba } \\
\text { University, } \\
\text { Japan }\end{array}$ & Coinvestigator & $\begin{array}{l}\text { Patient inclusion, } \\
\text { acquisition of data }\end{array}$ \\
\hline $\begin{array}{l}\text { K.A. Sheikh, } \\
\text { MD, PhD }\end{array}$ & $\begin{array}{l}\text { The University } \\
\text { of Texas } \\
\text { Health } \\
\text { Science } \\
\text { Center at } \\
\text { Houston }\end{array}$ & Coinvestigator & $\begin{array}{l}\text { Patient inclusion, } \\
\text { acquisition of data }\end{array}$ \\
\hline $\begin{array}{l}\text { N.J. Silvestri, } \\
\text { MD }\end{array}$ & $\begin{array}{l}\text { Buffalo } \\
\text { General } \\
\text { Medical } \\
\text { Center, NY }\end{array}$ & Coinvestigator & $\begin{array}{l}\text { Patient inclusion, } \\
\text { acquisition of data }\end{array}$ \\
\hline
\end{tabular}

Appendix 2 (continued)

\begin{tabular}{|c|c|c|c|}
\hline Name & Location & Role & Contribution \\
\hline $\begin{array}{l}\text { S.H. Sindrup, } \\
\text { MD, PhD }\end{array}$ & $\begin{array}{l}\text { Odense } \\
\text { University } \\
\text { Hospital, } \\
\text { Denmark }\end{array}$ & Coinvestigator & $\begin{array}{l}\text { Patient inclusion, } \\
\text { acquisition of data }\end{array}$ \\
\hline $\begin{array}{l}\text { C.L. } \\
\text { Sommer, MD }\end{array}$ & $\begin{array}{l}\text { Universität- } \\
\text { sklinikum } \\
\text { Würzburg, } \\
\text { Germany }\end{array}$ & Coinvestigator & $\begin{array}{l}\text { Patient inclusion, } \\
\text { acquisition of data }\end{array}$ \\
\hline B. Stein, MD & $\begin{array}{l}\text { St. Joseph's } \\
\text { Regional } \\
\text { Medical } \\
\text { Center, } \\
\text { Paterson, NJ }\end{array}$ & Coinvestigator & $\begin{array}{l}\text { Patient inclusion, } \\
\text { acquisition of data }\end{array}$ \\
\hline $\begin{array}{l}\text { A.M. Stino, } \\
\text { MD }\end{array}$ & $\begin{array}{l}\text { Wexner } \\
\text { Medical } \\
\text { Center at The } \\
\text { Ohio State } \\
\text { University, } \\
\text { Columbus }\end{array}$ & Coinvestigator & $\begin{array}{l}\text { Patient inclusion, } \\
\text { acquisition of data }\end{array}$ \\
\hline $\begin{array}{l}\text { A. } \\
\text { Spyropoulos, } \\
\text { MD }\end{array}$ & $\begin{array}{l}\text { Royal Victoria } \\
\text { Infirmary, } \\
\text { Newcastle } \\
\text { upon Tyne } \\
\text { Hospitals NHS } \\
\text { Foundation } \\
\text { Trust, } \\
\text { Newcastle, UK }\end{array}$ & Coinvestigator & $\begin{array}{l}\text { Patient inclusion, } \\
\text { acquisition of data }\end{array}$ \\
\hline $\begin{array}{l}\text { J. Srinivasan, } \\
\text { MD, PhD }\end{array}$ & $\begin{array}{l}\text { Lahey Hospital } \\
\& \text { Medical } \\
\text { Center, } \\
\text { Burlington, MA }\end{array}$ & Coinvestigator & $\begin{array}{l}\text { Patient inclusion, } \\
\text { acquisition of data }\end{array}$ \\
\hline $\begin{array}{l}\text { R. Styliani, } \\
\text { MD }\end{array}$ & $\begin{array}{l}\text { University of } \\
\text { Thessaly, } \\
\text { Hospital of } \\
\text { Larissa, } \\
\text { Greece }\end{array}$ & Coinvestigator & $\begin{array}{l}\text { Patient inclusion, } \\
\text { acquisition of data }\end{array}$ \\
\hline $\begin{array}{l}\text { H. Suzuki, } \\
\text { MD }\end{array}$ & $\begin{array}{l}\text { Kindai } \\
\text { University } \\
\text { Faculty of } \\
\text { Medicine, } \\
\text { Osaka, Japan }\end{array}$ & Coinvestigator & $\begin{array}{l}\text { Patient inclusion, } \\
\text { acquisition of data }\end{array}$ \\
\hline $\begin{array}{l}\text { H. Tankisi, } \\
\text { MD, PhD }\end{array}$ & $\begin{array}{l}\text { Aarhus } \\
\text { University } \\
\text { Hospital, } \\
\text { Denmark }\end{array}$ & Coinvestigator & $\begin{array}{l}\text { Patient inclusion, } \\
\text { acquisition of data }\end{array}$ \\
\hline $\begin{array}{l}\text { D. Tigner, } \\
\text { research } \\
\text { nurse }\end{array}$ & $\begin{array}{l}\text { University of } \\
\text { Calgary, } \\
\text { Canada }\end{array}$ & Coinvestigator & $\begin{array}{l}\text { Patient inclusion, } \\
\text { acquisition of data }\end{array}$ \\
\hline $\begin{array}{l}\text { P. Twydell, } \\
\text { DO, MS, } \\
\text { FAAN }\end{array}$ & $\begin{array}{l}\text { Spectrum } \\
\text { Health System, } \\
\text { Grand Rapids, } \\
\text { Ml }\end{array}$ & Coinvestigator & $\begin{array}{l}\text { Patient inclusion, } \\
\text { acquisition of data }\end{array}$ \\
\hline $\begin{array}{l}\text { P. Van } \\
\text { Damme, } \\
\text { MD, PhD }\end{array}$ & $\begin{array}{l}\text { University } \\
\text { Hospital } \\
\text { Leuven, } \\
\text { Belgium }\end{array}$ & Coinvestigator & $\begin{array}{l}\text { Patient inclusion, } \\
\text { acquisition of data }\end{array}$ \\
\hline $\begin{array}{l}\text { A.J. Van der } \\
\text { Kooi, MD, } \\
\text { PhD }\end{array}$ & $\begin{array}{l}\text { Amsterdam } \\
\text { UMC, } \\
\text { University of } \\
\text { Amsterdam, } \\
\text { Amsterdam } \\
\text { Neuroscience } \\
\text { Institute, the } \\
\text { Netherlands }\end{array}$ & Coinvestigator & $\begin{array}{l}\text { Patient inclusion, } \\
\text { acquisition of data }\end{array}$ \\
\hline
\end{tabular}


Appendix 2 (continued)

\begin{tabular}{|c|c|c|c|}
\hline Name & Location & Role & Contribution \\
\hline $\begin{array}{l}\text { G.W. Van } \\
\text { Dijk, MD }\end{array}$ & $\begin{array}{l}\text { Canisius } \\
\text { Wilhelmina } \\
\text { Hospital, } \\
\text { Nijmegen, the } \\
\text { Netherlands }\end{array}$ & Coinvestigator & $\begin{array}{l}\text { Patient inclusion, } \\
\text { acquisition of data }\end{array}$ \\
\hline $\begin{array}{l}\text { T. Van der } \\
\text { Ree, MD }\end{array}$ & $\begin{array}{l}\text { Westfries- } \\
\text { gasthuis, } \\
\text { Hoorn, the } \\
\text { Netherlands }\end{array}$ & Coinvestigator & $\begin{array}{l}\text { Patient inclusion, } \\
\text { acquisition of data }\end{array}$ \\
\hline $\begin{array}{l}\text { R. Van } \\
\text { Koningsveld, } \\
\text { MD, PhD }\end{array}$ & $\begin{array}{l}\text { Elkerliek } \\
\text { Hospital, } \\
\text { Helmond and } \\
\text { Deurne, the } \\
\text { Netherlands }\end{array}$ & Coinvestigator & $\begin{array}{l}\text { Patient inclusion, } \\
\text { acquisition of data }\end{array}$ \\
\hline $\begin{array}{l}\text { F. Valzania, } \\
\text { MD }\end{array}$ & $\begin{array}{l}\text { Arcispedale S. } \\
\text { Maria Nuova, } \\
\text { IRCCS Reggio } \\
\text { Emilia, Italy }\end{array}$ & Coinvestigator & $\begin{array}{l}\text { Patient inclusion, } \\
\text { acquisition of data }\end{array}$ \\
\hline $\begin{array}{l}\text { J.D. Varrato, } \\
\text { MD }\end{array}$ & $\begin{array}{l}\text { Lehigh Valley } \\
\text { Health } \\
\text { Network, } \\
\text { Allentown, PA }\end{array}$ & Coinvestigator & $\begin{array}{l}\text { Patient inclusion, } \\
\text { acquisition of data }\end{array}$ \\
\hline $\begin{array}{l}\text { F.H. Vermeij, } \\
\text { MD }\end{array}$ & $\begin{array}{l}\text { Sint } \\
\text { Franciscus } \\
\text { Gasthuis, } \\
\text { Rotterdam, } \\
\text { the } \\
\text { Netherlands }\end{array}$ & Coinvestigator & $\begin{array}{l}\text { Patient inclusion, } \\
\text { acquisition of data }\end{array}$ \\
\hline $\begin{array}{l}\text { J. } \\
\text { Verschuuren, } \\
\text { MD, PhD }\end{array}$ & $\begin{array}{l}\text { Leiden } \\
\text { University } \\
\text { Medical } \\
\text { Centre, the } \\
\text { Netherlands }\end{array}$ & Coinvestigator & $\begin{array}{l}\text { Patient inclusion, } \\
\text { acquisition of data }\end{array}$ \\
\hline $\begin{array}{l}\text { L.H. Visser, } \\
\text { MD, PhD }\end{array}$ & $\begin{array}{l}\text { Elisabeth- } \\
\text { TweeSteden } \\
\text { Hospital, } \\
\text { Tilburg and } \\
\text { Waalwijk, the } \\
\text { Netherlands }\end{array}$ & Coinvestigator & $\begin{array}{l}\text { Patient inclusion, } \\
\text { acquisition of data }\end{array}$ \\
\hline $\begin{array}{l}\text { M.V. Vytopil, } \\
\text { MD }\end{array}$ & $\begin{array}{l}\text { Lahey } \\
\text { Hospital \& } \\
\text { Medical } \\
\text { Center, } \\
\text { Burlington, } \\
\text { MA }\end{array}$ & Coinvestigator & $\begin{array}{l}\text { Patient inclusion, } \\
\text { acquisition of data }\end{array}$ \\
\hline $\begin{array}{l}\text { M. Wilken, } \\
\text { MD }\end{array}$ & $\begin{array}{l}\text { Instituto de } \\
\text { Investigaciones } \\
\text { Neurológicas } \\
\text { Raúl Carrea, } \\
\text { FLENI, Buenos } \\
\text { Aires, } \\
\text { Argentina }\end{array}$ & Coinvestigator & $\begin{array}{l}\text { Patient inclusion, } \\
\text { acquisition of data }\end{array}$ \\
\hline $\begin{array}{l}\text { C. } \\
\text { Wilkerson, } \\
\text { Research } \\
\text { Nurse }\end{array}$ & $\begin{array}{l}\text { The University } \\
\text { of Texas } \\
\text { Health } \\
\text { Science } \\
\text { Center at } \\
\text { Houston }\end{array}$ & Coinvestigator & $\begin{array}{l}\text { Patient inclusion, } \\
\text { acquisition of data }\end{array}$ \\
\hline $\begin{array}{l}\text { P.W. Wirtz, } \\
\text { MD, PhD }\end{array}$ & $\begin{array}{l}\text { Haga- } \\
\text { Ziekenhuis, } \\
\text { The Hague, } \\
\text { the } \\
\text { Netherlands }\end{array}$ & Coinvestigator & $\begin{array}{l}\text { Patient inclusion, } \\
\text { acquisition of data }\end{array}$ \\
\hline
\end{tabular}

Appendix 2 (continued)

\begin{tabular}{|c|c|c|c|}
\hline Name & Location & Role & Contribution \\
\hline $\begin{array}{l}\text { Y. } \\
\text { Yamagishi, } \\
\text { MD, PhD }\end{array}$ & $\begin{array}{l}\text { Kindai } \\
\text { University } \\
\text { Faculty of } \\
\text { Medicine, } \\
\text { Osaka, Japan }\end{array}$ & Coinvestigator & $\begin{array}{l}\text { Patient inclusion, } \\
\text { acquisition of data }\end{array}$ \\
\hline $\begin{array}{l}\text { L. Zhou, MD, } \\
\text { PhD }\end{array}$ & $\begin{array}{l}\text { Icahn School } \\
\text { of Medicine at } \\
\text { Mount Sinai, } \\
\text { New York }\end{array}$ & Coinvestigator & $\begin{array}{l}\text { Patient inclusion, } \\
\text { acquisition of data }\end{array}$ \\
\hline $\begin{array}{l}\text { S.A. } \\
\text { Zivkovic, } \\
\text { MD, PhD }\end{array}$ & $\begin{array}{l}\text { University of } \\
\text { Pittsburgh } \\
\text { Medical } \\
\text { Center, PA }\end{array}$ & Coinvestigator & $\begin{array}{l}\text { Patient inclusion, } \\
\text { acquisition of data }\end{array}$ \\
\hline
\end{tabular}

\section{References}

1. Chevret S, Hughes RA, Annane D. Plasma exchange for Guillain-Barré syndrome. Cochrane Database Syst Rev 2017;2:CD001798.

2. Hughes RA, Swan AV, van Doorn PA. Intravenous immunoglobulin for GuillainBarré syndrome. Cochrane Database Syst Rev 2014:CD002063.

3. Hughes RA, Swan AV, Raphaël JC, Annane D, van Koningsveld R, van Doorn PA. Immunotherapy for Guillain-Barré syndrome: a systematic review. Brain 2007;130: 2245-2257.

4. Wakerley BR, Uncini A, Yuki N; Group GBSC. Guillain-Barre and Miller Fisher syndromes: new diagnostic classification. Nat Rev Neurol 2014;10:537-544.

5. Overell JR, Hsieh ST, Odaka M, Yuki N, Willison HJ. Treatment for Fisher syndrome, Bickerstaff's brainstem encephalitis and related disorders. Cochrane Database Syst Rev 2007:CD004761.

6. Willison HJ, Jacobs BC, van Doorn PA. Guillain-Barré syndrome. Lancet 2016;388: 717-727.

7. Verboon C, van Doorn PA, Jacobs BC. Treatment dilemmas in Guillain-Barré syndrome. J Neurol Neurosurg Psychiatry 2017;88:346-352.

8. Jacobs BC, van den Berg B, Verboon C, et al. International Guillain-Barré Syndrome Outcome Study: protocol of a prospective observational cohort study on clinical and biological predictors of disease course and outcome in Guillain-Barré syndrome. J Peripher Nerv Syst 2017;22:68-76.

9. Islam Z, Jacobs BC, van Belkum A, et al. Axonal variant of Guillain-Barre syndrome associated with Campylobacter infection in Bangladesh. Neurology 2010;74:581-587.

10. Ishaque T, Islam MB, Ara G, Endtz QD, Jacobs BC, Islam Z. High mortality from Guillain-Barré syndrome in Bangladesh. J Peripher Nerv Syst 2017;22:121-126.

11. Doets AY, Verboon C, van den Berg B, et al. Regional variation of Guillain-Barré syndrome. Brain 2018;141:2866-2877.

12. The French Cooperative Group on Plasma Exchange in Guillain-Barre Syndrome. Appropriate number of plasma exchanges in Guillain-Barre syndrome.Ann Neurol 1997;41:298-306.

13. Hadden RD, Cornblath DR, Hughes RA, Zielasek HP, Toyka KV, Swan AV. Electrophysiological classification of Guillain-Barré syndrome: clinical associations and outcome: Plasma Exchange/Sandoglobulin Guillain-Barré Syndrome Trial Group. Ann Neurol 1998;44:780-788.

14. Kleyweg RP, van der Meché FG, Schmitz PI. Interobserver agreement in the assessment of muscle strength and functional abilities in Guillain-Barré syndrome. Muscle Nerve 1991;14:1103-1109.

15. Hughes RA, Newsom-Davis JM, Perkin GD, Pierce JM. Controlled trial of prednisolone in acute polyneuropathy. Lancet 1978;2:750-753.

16. Walgaard C, Jacobs BC, Lingsma HF, Steyerberg DR, van Doorn PA. Second IVIg course in Guillain-Barré syndrome patients with poor prognosis (SID-GBS trial): protocol for a double-blind randomized, placebo-controlled clinical trial. J Peripher Nerv Syst 2018;23:210-215.

17. Davidson AI, Halstead SK, Goodfellow JA, et al. Inhibition of complement in GuillainBarré syndrome: the ICA-GBS study. J Peripher Nerv Syst 2017;22:4-12.

18. Korinthenberg R, Schessl J, Kirschner J, Mönting JS. Intravenously administered immunoglobulin in the treatment of childhood Guillain-Barré syndrome: a randomized trial. Pediatrics 2005;116:8-14.

19. Hughes RA, Brassington R, Gunn AA, van Doorn PA. Corticosteroids for GuillainBarré syndrome. Cochrane Database Syst Rev 2016;10:CD001446.

20. Plasma Exchange/Sandoglobulin Guillain-Barre Syndrome Trial Group. Randomised trial of plasma exchange, intravenous immunoglobulin, and combined treatments in Guillain-Barre syndrome.Lancet 1997;349:225-230.

21. van der Meche FG, Schmitz PI. A randomized trial comparing intravenous immune globulin and plasma exchange in Guillain-Barre syndrome: Dutch Guillain-Barre Study Group. N Engl J Med 1992;326:1123-1129. 
22. Haupt WF, Rosenow F, van der Ven C, Borberg H, Pawlik G. Sequential treatment of Guillain-Barré syndrome with extracorporeal elimination and intravenous immunoglobulin. J Neurol Sci 1996;137:145-149.

23. Diener HC, Haupt WF, Kloss TM, Rosenow T, Koeppen S, Vietorisz A. A preliminary, randomized, multicenter study comparing intravenous immunoglobulin, plasma exchange, and immune adsorption in Guillain-Barré syndrome. Eur Neurol 2001;46:107-109.

24. Hughes RA, van Doorn PA. Corticosteroids for Guillain-Barré syndrome. Cochrane Database Syst Rev 2012;8:CD001446.
25. Islam MB, Islam Z, Rahman S, et al. Small volume plasma exchange for Guillain-Barre syndrome in resource poor settings: a safety and feasibility study. Pilot Feasibility Stud 2017;3:40.

26. Mori M, Kuwabara S, Fukutake T, Yuki N, Hattori T. Clinical features and prognosis of Miller Fisher syndrome. Neurology 2001;56:1104-1106.

27. van Koningsveld R, Schmitz PI, Meché FG, Visser J, van Doorn PA. Effect of methylprednisolone when added to standard treatment with intravenous immunoglobulin for Guillain-Barré syndrome: randomised trial. Lancet 2004;363: 192-196. 


\title{
Neurology
}

\author{
Current treatment practice of Guillain-Barré syndrome \\ Christine Verboon, Alex Y. Doets, Giuliana Galassi, et al.
}

Neurology 2019;93;e59-e76 Published Online before print June 7, 2019

DOI 10.1212/WNL.0000000000007719

This information is current as of June 7, 2019

\section{Updated Information \& Services}

\section{References}

Citations

Subspecialty Collections

Permissions \& Licensing

Reprints including high resolution figures, can be found at: http://n.neurology.org/content/93/1/e59.full

This article cites 25 articles, 4 of which you can access for free at: http://n.neurology.org/content/93/1/e59.full\#ref-list-1

This article has been cited by 1 HighWire-hosted articles: http://n.neurology.org/content/93/1/e59.full\#\#otherarticles

This article, along with others on similar topics, appears in the following collection(s):

Guillain-Barre syndrome

http://n.neurology.org/cgi/collection/guillainbarre_syndrome

Health policy

http://n.neurology.org/cgi/collection/health_policy

Medical care

http://n.neurology.org/cgi/collection/medical_care

Models of care

http://n.neurology.org/cgi/collection/models_of_care

Information about reproducing this article in parts (figures,tables) or in its entirety can be found online at:

http://www.neurology.org/about/about_the_journal\#permissions

Information about ordering reprints can be found online:

http://n.neurology.org/subscribers/advertise

Neurology ${ }^{\circledR}$ is the official journal of the American Academy of Neurology. Published continuously since 1951, it is now a weekly with 48 issues per year. Copyright @ 2019 American Academy of Neurology. All rights reserved. Print ISSN: 0028-3878. Online ISSN: 1526-632X.

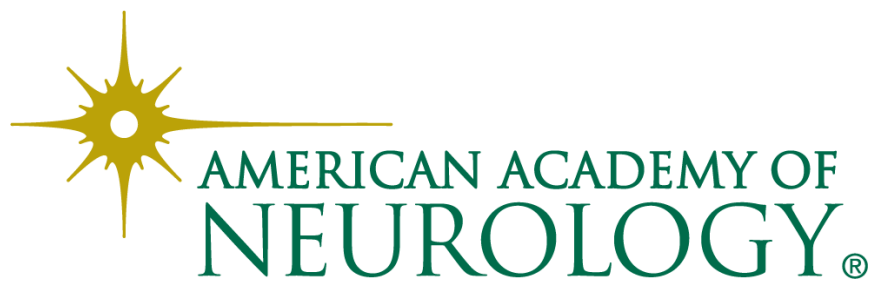

